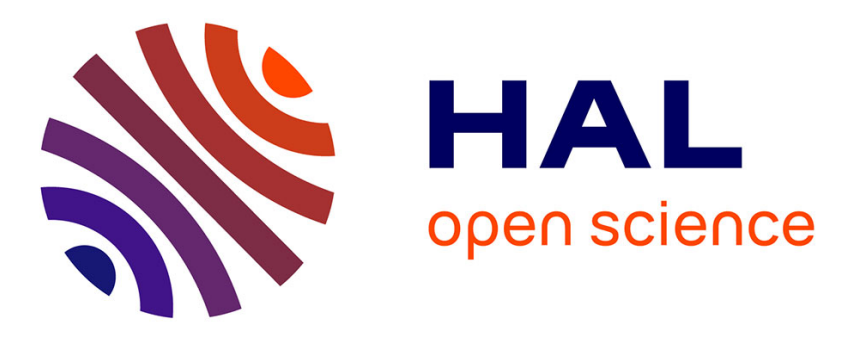

\title{
Cancer Cell Death Induced by Phosphine Gold(I) Compounds Targeting Thioredoxin Reductase
}

\author{
Valentina Gandin, Aristi Potamitou Fernandes, Maria Pia Rigobello, Barbara \\ Dani, Francesca Sorrentino, Francesco Tisato, Mikael Björnstedt, Alberto \\ Bindoli, Alberto Sturaro, Rocco Rella, et al.
}

\section{To cite this version:}

Valentina Gandin, Aristi Potamitou Fernandes, Maria Pia Rigobello, Barbara Dani, Francesca Sorrentino, et al.. Cancer Cell Death Induced by Phosphine Gold(I) Compounds Targeting Thioredoxin Reductase. Biochemical Pharmacology, 2009, 79 (2), pp.90. 10.1016/j.bcp.2009.07.023 . hal00535818

\section{HAL Id: hal-00535818 \\ https://hal.science/hal-00535818}

Submitted on 13 Nov 2010

HAL is a multi-disciplinary open access archive for the deposit and dissemination of scientific research documents, whether they are published or not. The documents may come from teaching and research institutions in France or abroad, or from public or private research centers.
L'archive ouverte pluridisciplinaire HAL, est destinée au dépôt et à la diffusion de documents scientifiques de niveau recherche, publiés ou non, émanant des établissements d'enseignement et de recherche français ou étrangers, des laboratoires publics ou privés. 


\section{Accepted Manuscript}

Title: Cancer Cell Death Induced by Phosphine Gold(I)

Compounds Targeting Thioredoxin Reductase

Authors: Valentina Gandin, Aristi Potamitou Fernandes, Maria Pia Rigobello, Barbara Dani, Francesca Sorrentino, Francesco Tisato, Mikael Björnstedt, Alberto Bindoli, Alberto

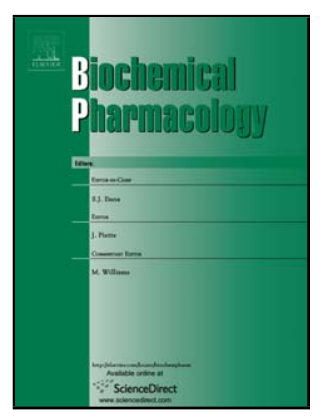

Sturaro, Rocco Rella, Cristina Marzano

PII:

S0006-2952(09)00675-3

DOI: doi:10.1016/j.bcp.2009.07.023

Reference: BCP 10279

To appear in: $\quad B C P$

Received date: $\quad$ 12-6-2009

Revised date: 28-7-2009

Accepted date: $\quad 30-7-2009$

Please cite this article as: Gandin V, Fernandes AP, Rigobello MP, Dani B, Sorrentino F, Tisato F, Björnstedt M, Bindoli A, Sturaro A, Rella R, Marzano C, Cancer Cell Death Induced by Phosphine Gold(I) Compounds Targeting Thioredoxin Reductase, Biochemical Pharmacology (2008), doi:10.1016/j.bcp.2009.07.023

This is a PDF file of an unedited manuscript that has been accepted for publication. As a service to our customers we are providing this early version of the manuscript. The manuscript will undergo copyediting, typesetting, and review of the resulting proof before it is published in its final form. Please note that during the production process errors may be discovered which could affect the content, and all legal disclaimers that apply to the journal pertain. 


\section{Cancer Cell Death Induced by Phosphine Gold(I)}

\section{Compounds Targeting Thioredoxin Reductase}

Valentina Gandin ${ }^{a}$; Aristi Potamitou Fernandes ${ }^{b}$, Maria Pia Rigobello $^{c}$, Barbara Dani $^{c}$, Francesca Sorrentino $^{c}$, Francesco Tisato $^{d}$, Mikael Björnstedt ${ }^{b}$, Alberto Bindoli ${ }^{e}$, Alberto Sturaro ${ }^{f}$, Rocco Rella ${ }^{f}$ and Cristina $\operatorname{Marzano}^{* a}$;

a. Dipartimento di Scienze Farmaceutiche, Università di Padova, Via Marzolo 5, 35121 Padova, Italy

b. Karolinska Institutet, Department of Laboratory Medicine, Division of Pathology F46, Karolinska University Hospital Huddinge, SE-141 86 Stockholm, Sweden

c. Dipartimento di Chimica Biologica, Università di Padova, Viale G. Colombo 3, 35121 Padova, Italy

d. ICIS-C.N.R., Corso Stati Uniti, 4, 35127 Padova, Italy

e. Istituto di Neuroscienze (CNR), Viale G. Colombo 3, 35121 Padova, Italy

f. IDPA-C.N.R., Corso Stati Uniti, 4, 35127 Padova, Italy

*Corresponding author: Cristina Marzano, Via Marzolo,5 35131 Padova. Tel. +39 498275365 Fax. +39 49 8275366 E-mail: cristina.marzano@unipd.it 

5

\section{Abstract}

The thioredoxin system, composed of thioredoxin reductase (TrxR), thioredoxin (Trx), and NADPH (Nicotinamide adenine dinucleotide phosphate), plays a central role in regulating cellular redox homeostasis and signaling pathways. TrxR, overexpressed in many tumor cells and contributing to drug resistance, has emerged as a new target for anticancer drugs. Gold complexes have been validated as potent TrxR inhibitors in vitro in the nanomolar range. In order to obtain potent and selective TrxR inhibitors, we have synthesized a series of linear, 'auranofin-like' gold(I) complexes all containing the $\left[\mathrm{Au}\left(\mathrm{PEt}_{3}\right)\right]^{+}$synthon and the ligands: $\mathrm{Cl}^{-}, \mathrm{Br}^{-}$, cyanate, thiocyanate, ethylxanthate, diethyldithiocarbamate and thiourea. Phosphine gold(I) complexes efficiently inhibited cytosolic and mitochondrial TrxR at concentrations that did not affect the two related oxidoreductases glutathione reductase (GR) and glutathione peroxidase (GPx). The inhibitory effect of the redox proteins was also observed intracellularly in cancer cells pretreated with gold(I) complexes. Gold(I) compounds were found to induce antiproliferative effects towards several human cancer cells some of which endowed with cisplatin or multidrug resistance. In addition, they were able to activate caspase-3 and induce apoptosis observed as nucleosome formation and sub-G1 cell accumulation. The complexes with thiocyanate and xanthate ligands were particularly effective in inhibiting thioredoxin reductase and inducing apoptosis. Pharmacodynamic studies in human ovarian cancer cells allowed for the correlatation of intracellular drug accumulation with TrxR inhibition that leads to the induction of apoptosis via the mitochondrial pathway.

Keywords: Thioredoxin reductase, phosphine metal complexes, apoptosis, drug resistance, cytotoxicity, oxidative stress . .

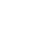

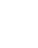
. . 


\section{Introduction}

Auranofin, triethylphosphine(2,3,4,6-tetra-O-acetyl- $\beta$-1-D-thiopyranosato-S)gold(I), is the first metal phosphine complex introduced into clinical practice for chrysotherapy, the treatment of rheumatoid arthritis with gold-based drugs [1], following the pioneering studies conducted with gold(I) thiolate compounds [2]. In contrast to the polymeric nature of the latter, auranofin is a discrete monomeric complex [3] composed of a tertiary phosphine and a thioglucose coordinated to the metal having bond lengths and angles [3] similar to those of typical two-coordinate, linear gold(I) compounds [4]. In this simple molecule the neutral triethylphosphine ligand was described as conferring membrane permeability while the mono-anionic tetraacetylthioglucose was reported as being displaced quite rapidly in vivo. Extensive multinuclear $\left({ }^{1} \mathrm{H},{ }^{13} \mathrm{C}\right.$ and $\left.{ }^{31} \mathrm{P}\right)$ NMR studies, which focused on the interaction of auranofin with serum albumin, have established that the drug appears to react at the albumin cys-34 site via a ligand-exchange reaction that displaces the sulphydryl group [5]. Both deacetylated auranofin and the parent $\left[\mathrm{AuCl}\left(\mathrm{PEt}_{3}\right)\right]$ complex form the same $\left[\left(\mathrm{Et}_{3} \mathrm{P}\right) \mathrm{Au}(\mathrm{S}-\mathrm{alb})\right]$ adduct by displacement of the anion. By studying reactions with auranofin instead of the unstable deacetylated form, under conditions approximating those in vivo, such adduct formation is of the first-order in auranofin with a rate constant of $2.9 \pm 0.2 \mathrm{~s}^{-1}$ [6]. These data support the view that auranofin (or its deacetylated metabolite) should have a very short lifetime after entering the bloodstream where albumin is present in excessive amount (10-40 fold) compared to the gold drug [6]. To corroborate this hypothesis, Christodoulou et al. [7] reported a conformational change in albumin that accompanies gold binding to cys-34. Taken together the above studies indicate that the pharmacokinetic of auranofin appears to be markedly affected by the lability of the metalthioglucose bond, thereby suggesting that subtle modification of this interaction could produce changes in the biological profile of the drug.

Auranofin was shown to possess in vivo antitumor activity against P388 murine leukemia and in vitro cytotoxic potency against both B16 melanoma and P388 leukemia cells for two decades [8]. However, very recently, additional in vitro studies indicated that auranofin is able to overcome cisplatin resistance in human 
1 ovarian cancer cells [9], confirming the earlier assumption that a mechanism of action different from the

2

3 4 5

recognized DNA damage induced by cisplatin could underlie the cytotoxic activity of phosphine Au(I) drugs. In particular, it was found that auranofin, acting as a potent inhibitor of thioredoxin reductase, causes an alteration of the redox state of the cell leading to an increased production of hydrogen peroxide and oxidation of the components of the thioredoxin (Trx) system, therefore creating the conditions for enhanced apoptosis [9].

Among TrxR inhibitors, gold compounds are very effective, acting at nanomolar levels, probably due to the high affinity of gold towards chalcogenides (group 16 donors including S, Se and Te) which renders the nucleophilic selenolate of reduced TrxR the prime target site of modification by this metal. Hence, as pointed out above, the linear structure of auranofin and especially the lability of the thioglucose group appears to play a peculiar role both in the pharmacokinetic profile and in the cytotoxic effect of this molecule. It was also shown that phosphinegold(I) thiolates were more cytotoxic than gold(I) thiolates, and that phosphinegold(I) thiolates had more promising cytotoxicity profiles than their chloride analogues, indicating the importance of both the phosphine and the thiolate ligand for cytotoxic activity. We have consequently synthesized a series of 'auranofin-like' gold(I) complexes maintaining intact the $\left[\mathrm{Au}\left(\mathrm{PEt}_{3}\right)\right]^{+}$moiety and replacing the thioglucose anion with other mono-dentate ligands which have binding potential to gold(I). This series comprises of common gold(I) precursors such as $\left[\mathrm{AuCl}\left(\mathrm{PEt}_{3}\right)\right](\mathbf{1})$ and $\left[\mathrm{AuBr}\left(\mathrm{PEt}_{3}\right)\right](\mathbf{2})$ along with complexes containing mainly sulfur donor atoms having different nucleophilicity such as diethyldithiocarbamate (dedc), xanthate (xant), thiocyanate (SCN), thiourea (tu), and cyanate $(\mathrm{CN})$ (see Scheme 1). The choice of these co-ligands was based on the rationale to optimize or customize TrxR inhibition by changing the thioglucose residue of auranofin, and on the availability of relatively simple synthetic procedures already reported in the literature for the preparation of linear phosphine gold(I) complexes. Thiocyanate and cyanide represent gold ligands involved in human metabolism of auranofin-like gold(I) complexes whose major pathway implicates myeloperoxidase [10]. Dithiocarbamates (DTCs) and xanthate are well known heavy-metal chelating agents which possess various biological activities [11]. Due to their lipophilic character, they may allow the formation of bioactive metal complexes with great tendency to cross the cell membrane by passive diffusion. Certain phosphine gold(I) 
1 xanthate and dithiocarbamate compounds have proved to possess antiarthritic and in vitro antitumor activities 2

[12]. Moreover, some gold(III)-DTC complexes have recently demonstrated an outstanding potential as

5

6 anticancer agents able to overcome cisplatin resistance [13].

7

8

In the current study we have assessed the antitumor properties of these gold(I) compounds towards a wide panel of human cancer cell lines also including cisplatin and multidrug resistant (MDR) phenotypes. Gold(I) complexes were evaluated for their capacity to inhibit cytosolic and/or mitochondrial isoforms of TrxR, both in vitro (in a cell-free system) and in human ovarian cancer cells. The inactivation of the closely related enzymes glutathione reductase (GR) and glutathione peroxidase (GPx) was also examined with the aim of assessing gold(I) complex selectivity. Finally, reactive oxygen species (ROS) production and triggering of apoptosis in treated cancer cells, consequent to cellular TrxR targeting, have been investigated. 


\section{Material and methods}

\subsection{Synthesis}

All reagents and $\left[\mathrm{AuCl}\left(\mathrm{PEt}_{3}\right)\right],(\mathbf{1})$, were purchased from Aldrich (St. Louis, MO, USA) and used without further purification. Phosphine gold(I) complexes were prepared in accordance with published procedures.

2.1.1. [AuBr(PEt 3$)$ ], (2), was prepared as described by El-Etri et al. [14] ${ }^{1} \mathrm{H} \mathrm{NMR}\left(\mathrm{CDCl}_{3}, \delta\right) 1.21(\mathrm{dt}$, $\left.\mathrm{P}\left(\mathrm{CH}_{2} \mathrm{CH}_{3}\right)_{3}, 9 \mathrm{H} ;{ }^{3} J_{\mathrm{HH}}=7.6 \mathrm{~Hz},{ }^{3} J_{\mathrm{HP}}=18.9 \mathrm{~Hz}\right), 1.84\left(\mathrm{dq}, \mathrm{P}\left(\mathrm{CH}_{2} \mathrm{CH}_{3}\right)_{3}, 6 \mathrm{H} ;{ }^{3} J_{\mathrm{HH}}=7.6 \mathrm{~Hz},{ }^{3} J_{\mathrm{HP}}=18.9 \mathrm{~Hz}\right)$. $\left.{ }^{13} \mathrm{C}\left\{{ }^{1} \mathrm{H}\right\} \mathrm{NMR}\left(\mathrm{CDCl}_{3}, \delta\right) 11.78\left(\mathrm{~s}, \mathrm{P}\left(\mathrm{CH}_{2} \mathrm{CH}_{3}\right)_{3}\right), 21.02\left(\mathrm{~d}, \mathrm{P}\left(\mathrm{CH}_{2} \mathrm{CH}_{3}\right)_{3}\right) ;{ }^{1} J_{\mathrm{CP}}=35.9 \mathrm{~Hz}\right) .{ }^{31} \mathrm{P}\left\{{ }^{1} \mathrm{H}\right\} \mathrm{NMR}$ $\left(\mathrm{CDCl}_{3}, \delta\right) 35.18(\mathrm{~s})$

2.1.2. $\left[\mathrm{Au}(\mathrm{CN})\left(\mathrm{PEt}_{3}\right)\right],(3)$, was prepared as described by El-Etri et al. [14] ${ }^{1} \mathrm{H} \mathrm{NMR}\left(\mathrm{CDCl}_{3}, \delta\right) 1.21(\mathrm{dt}$, $\left.\mathrm{P}\left(\mathrm{CH}_{2} \mathrm{CH}_{3}\right)_{3}, 9 \mathrm{H} ;{ }^{3} J_{\mathrm{HH}}=7.6 \mathrm{~Hz},{ }^{3} J_{\mathrm{HP}}=18.6 \mathrm{~Hz}\right), 1.84\left(\mathrm{~m}, \mathrm{P}\left(\mathrm{CH}_{2} \mathrm{CH}_{3}\right)_{3}, 6 \mathrm{H}\right) .{ }^{31} \mathrm{P}\left\{{ }^{1} \mathrm{H}\right\} \mathrm{NMR}\left(\mathrm{CDCl}_{3}, \delta\right) 36.81$ (s).

2.1.3. $\left[\mathrm{Au}(\mathrm{SCN})\left(\mathrm{PEt}_{3}\right)\right],(4)$, was prepared as described by El-Etri et al. $[14]{ }^{1} \mathrm{H} \mathrm{NMR}\left(\mathrm{CDCl}_{3}, \delta\right) 1.23(\mathrm{dt}$, $\left.\mathrm{P}\left(\mathrm{CH}_{2} \mathrm{CH}_{3}\right)_{3}, 9 \mathrm{H} ;{ }^{3} J_{\mathrm{HH}}=7.6 \mathrm{~Hz},{ }^{3} J_{\mathrm{HP}}=18.6 \mathrm{~Hz}\right), 1.89\left(\mathrm{~m}, \mathrm{P}\left(\mathrm{CH}_{2} \mathrm{CH}_{3}\right)_{3}, 6 \mathrm{H}\right),{ }^{31} \mathrm{P}\left\{{ }^{1} \mathrm{H}\right\} \mathrm{NMR}\left(\mathrm{CDCl}_{3}, \delta\right) 37.23$ (s).

2.1.4. [Au(dedc) $\left.\left(\mathrm{PEt}_{3}\right)\right]$, (5) was prepared according to de Vos et al. [11] ${ }^{1} \mathrm{H} \mathrm{NMR}\left(\mathrm{CDCl}_{3}, \delta\right) 1.19(\mathrm{t}$, $\left.>\mathrm{CN}\left(\mathrm{CH}_{2} \mathrm{CH}_{3}\right)_{2}, 6 \mathrm{H} ;{ }^{3} J_{\mathrm{HH}}=7.6 \mathrm{~Hz}\right), 1.21\left(\mathrm{dt}, \mathrm{P}\left(\mathrm{CH}_{2} \mathrm{CH}_{3}\right)_{3}, 9 \mathrm{H} ;{ }^{3} J_{\mathrm{HH}}=7.6 \mathrm{~Hz},{ }^{3} J_{\mathrm{HP}}=18.9 \mathrm{~Hz}\right), 1.83(\mathrm{~m}$, $\left.\mathrm{P}\left(\mathrm{CH}_{2} \mathrm{CH}_{3}\right)_{3}, 6 \mathrm{H}\right), 3.89\left(\mathrm{q},>\mathrm{N}\left(\mathrm{CH}_{2} \mathrm{CH}_{3}\right)_{2}, 4 \mathrm{H} ;{ }^{3} J_{\mathrm{HH}}=7.6 \mathrm{~Hz}\right) .{ }^{13} \mathrm{C}\left\{{ }^{1} \mathrm{H}\right\} \mathrm{NMR}\left(\mathrm{CDCl}_{3}, \delta\right) 11.72(\mathrm{~s}$, $\left.\left.\mathrm{P}\left(\mathrm{CH}_{2} \mathrm{CH}_{3}\right)_{3}\right), 15.00\left(\mathrm{~s},>\mathrm{N}\left(\mathrm{CH}_{2} \mathrm{CH}_{3}\right)_{2}\right), 21.33\left(\mathrm{~d}, \mathrm{P}\left(\mathrm{CH}_{2} \mathrm{CH}_{3}\right)_{3}\right) ;{ }^{1} \mathrm{~J}_{\mathrm{CP}}=33.6 \mathrm{~Hz}\right) .{ }^{31} \mathrm{P}\left\{{ }^{1} \mathrm{H}\right\} \mathrm{NMR}\left(\mathrm{CDCl}_{3}, \delta\right)$ $34.76(\mathrm{~s})$ 
2.1.5. [Au(xant)(PEt $)]$, (6) was prepared according to de Vos et al. [11] $\left.{ }^{1} \mathrm{H} \mathrm{NMR}\left(\mathrm{CDCl}_{3}, \delta\right)\right), 1.25$ (dt, $\left.\mathrm{P}\left(\mathrm{CH}_{2} \mathrm{CH}_{3}\right)_{3}, 9 \mathrm{H} ;{ }^{3} J_{\mathrm{HH}}=7.6 \mathrm{~Hz},{ }^{3} J_{\mathrm{HP}}=18.9 \mathrm{~Hz}\right), 1.39\left(\mathrm{t},>\mathrm{COCH}_{2} \mathrm{CH}_{3}, 3 \mathrm{H} ;{ }^{3} J_{\mathrm{HH}}=7.1 \mathrm{~Hz}\right) 1.84(\mathrm{~m}$, $\left.\mathrm{P}\left(\mathrm{CH}_{2} \mathrm{CH}_{3}\right)_{3}, 6 \mathrm{H}\right), 4.50\left(\mathrm{q},>\mathrm{COCH}_{2} \mathrm{CH}_{3}, 2 \mathrm{H} ;{ }^{3} J_{\mathrm{HH}}=7.1 \mathrm{~Hz}\right) .{ }^{13} \mathrm{C}\left\{{ }^{1} \mathrm{H}\right\} \mathrm{NMR}\left(\mathrm{CDCl}_{3}, \delta\right) 11.84\left(\mathrm{~s}, \mathrm{P}_{\left.\left(\mathrm{CH}_{2} \mathrm{CH}_{3}\right)_{3}\right)}\right.$, $\left.16.91\left(\mathrm{~s},>\mathrm{COCH}_{2} \mathrm{CH}_{3}\right), 21.02\left(\mathrm{~d}, \mathrm{P}\left(\mathrm{CH}_{2} \mathrm{CH}_{3}\right)_{3}\right) ;{ }^{1} \mathrm{~J}_{\mathrm{CP}}=33.9 \mathrm{~Hz}\right) .{ }^{31} \mathrm{P}\left\{{ }^{1} \mathrm{H}\right\} \mathrm{NMR}\left(\mathrm{CDCl}_{3}, \delta\right) 36.65(\mathrm{~s})$.

2.1.6. [ $\left.\mathrm{Au}(\mathrm{tu})\left(\mathrm{PEt}_{3}\right)\right][\mathrm{Cl}],(7)$, was synthesised by the method used by Coates et al. [15] to prepare the bromide analog. ${ }^{1} \mathrm{H}$ NMR $\left(\right.$ dmso-d $\left.\mathrm{d}_{6}, \delta\right) 1.09\left(\mathrm{dt}, \mathrm{P}\left(\mathrm{CH}_{2} \mathrm{CH}_{3}\right)_{3}, 9 \mathrm{H} ;{ }^{3} J_{\mathrm{HH}}=7.6 \mathrm{~Hz},{ }^{3} J_{\mathrm{HP}}=19.2 \mathrm{~Hz}\right), 1.90(\mathrm{~m}$, $\left.\mathrm{P}\left(\mathrm{CH}_{2} \mathrm{CH}_{3}\right)_{3}, 6 \mathrm{H}\right), 7.27$ (broad s, 4H; SC $\left.\left(\mathrm{NH}_{2}\right)_{2}\right) .{ }^{31} \mathrm{P}\left\{{ }^{1} \mathrm{H}\right\} \mathrm{NMR}\left(\mathrm{CDCl}_{3}, \delta\right) 36.31(\mathrm{~s})$.

2.1.7. $\left[\mathrm{Au}\left(2,3,4,6\right.\right.$-tetra-O-acetyl- $\beta$-1-D-thiopyranosato-S)( $\left.\left.\mathrm{PEt}_{3}\right)\right],(8)$ Auranofin was obtained from Alexis Biochemicals (Lausen, Switzerland) or it was prepared according to Sutton et al. [16] ${ }^{1} \mathrm{H}$ NMR $\left(\mathrm{CDCl}_{3}, \delta\right) 1.22$ $\left(\mathrm{dt}, \mathrm{P}\left(\mathrm{CH}_{2} \mathrm{CH}_{3}\right)_{3}, 9 \mathrm{H} ;{ }^{3} J_{\mathrm{HH}}=7.6 \mathrm{~Hz},{ }^{3} J_{\mathrm{HP}}=18.4 \mathrm{~Hz}\right), 1.85\left(\mathrm{~m}, \mathrm{P}\left(\mathrm{CH}_{2} \mathrm{CH}_{3}\right)_{3}, 6 \mathrm{H}\right), 1.98,2.01,2.05$ and 2.08 (four s, $\left.-\mathrm{OCH}_{3}, 3+3+3+3 \mathrm{H}\right), 3.71(\mathrm{bs}, 1 \mathrm{H}), 4.09(\mathrm{~d}, 1 \mathrm{H}), 4.24(\mathrm{dd}, 1 \mathrm{H}), 4.99(\mathrm{~m}, 1 \mathrm{H}), 5.12(\mathrm{~m}, 3 \mathrm{H})($ methine and methylene $\mathrm{H}$ of the thioglucopyranosato backbone). ${ }^{31} \mathrm{P}\left\{{ }^{1} \mathrm{H}\right\} \mathrm{NMR}\left(\mathrm{CDCl}_{3}, \delta\right) 38.06$ (s).

\subsection{Experiments with human cells}

Cisplatin, auranofin and the synthesized complexes, along with the corresponding uncoordinated ligands, were dissolved in DMSO, just before the experiment. Calculated amounts of drug solution were added to the growth medium to a final solvent concentration of $0.5 \%$, which had no discernible effect on cell killing. MTT (3-(4,5-dimethylthiazol-2-yl)-2,5-diphenyltetrazolium bromide) and cisplatin were obtained from SigmaAldrich, St. Louis, MO, USA.

2.2.1. Cell cultures. Human lung (A549), breast (MCF-7), colon (HCT-15) and cervix (HeLa) carcinoma cell lines along with melanoma (A375) and promyelocytic leukemia (HL60) cell lines were obtained by ATCC, 
1 Rockville, MD. 2008 cell line, its cisplatin-resistant (C13*) and -revertant (RH4) variants, , are human ovarian

2

3

cancer cells kindly provided by Prof. G. Marverti (Dept. of Biomedical Science of Modena University, Italy).

A431 and A431-Pt are sensitive and resistant human cervix carcinoma cells, respectively; they were kindly

provided by Prof. F. Zunino (Division of Experimental Oncology B, Istituto Nazionale dei Tumori, Milan,

Italy). LoVo human colon-carcinoma cell line and its derivative multidrug-resistant subline (LoVo MDR) were

kindly provided by Prof. F. Majone (Department of Biology of Padova University, Italy). The human parental lung carcinoma U1285 cell line was obtained from ATCC (American Type Culture Collection) whereas its doxorubicin-resistant subline U1285dox, was selected to tolerate $1.6 \mu \mathrm{M}$ doxorubicin as previously described [17]. Cell lines were maintained in the logarithmic phase at $37^{\circ} \mathrm{C}$ in a $5 \%$ carbon dioxide atmosphere using the following culture media containing $10 \%$ foetal calf serum (Euroclone, Milan, Italy), antibiotics (50 units $\mathrm{mL}^{-1}$ penicillin and $50 \mu \mathrm{g} \cdot \mathrm{mL}^{-1}$ streptomycin) and 2mM 1-glutamine : i) RPMI-1640 medium (Euroclone) with 25 mM HEPES buffer for HL60, MCF-7, HCT-15, 2008, C13*, RH4, A431, A431-Pt, U1285 and U1285dox cells; ii) F-12 HAM'S (Sigma-Aldrich) for HeLa, LoVo and LoVo MDR cells; iii) D-MEM medium (Euroclone), for A549 and A375 cells. LoVo MDR culture medium also contained $0.1 \mu \mathrm{g} \cdot \mathrm{mL}^{-1}$ doxorubicin.

2.2.2. Cytotoxicity assay. The growth inhibitory effect towards tumor cell lines was evaluated by means of MTT (tetrazolium salt reduction) assay [18]. Briefly, $3-8 \cdot 10^{3}$ cells/well, dependent upon the growth characteristics of the cell line, were seeded in 96-well microplates in growth medium $(100 \mu \mathrm{L})$ and then incubated at $37^{\circ} \mathrm{C}$ in a $5 \%$ carbon dioxide atmosphere. After $24 \mathrm{~h}$, the medium was removed and replaced with a fresh one containing the compound to be studied at the appropriate concentration. Triplicate cultures were established for each treatment. After 48 or $72 \mathrm{~h}$, each well was treated with $10 \mu \mathrm{L}$ of a $5 \mathrm{mg} \cdot \mathrm{mL}^{-1}$ MTT (3-(4,5dimethylthiazol-2-yl)-2,5-diphenyltetrazolium bromide) saline solution, and after $5 \mathrm{~h}$ of incubation, $100 \mu \mathrm{L}$ of a sodium dodecylsulfate (SDS) solution in $\mathrm{HCl} 0.01 \mathrm{M}$ was added. After overnight incubation, the inhibition of cell growth induced by the tested complexes was detected by measuring the absorbance of each well at $570 \mathrm{~nm}$ using a Bio-Rad 680 microplate reader. Mean absorbance for each drug dose was expressed as a percentage of 


\section{1}

3

2.2.3. Cellular uptake. $2 \cdot 10^{6} 2008$ cells were seeded in $75 \mathrm{~cm}^{2}$ flasks in growth medium $(20 \mathrm{~mL})$. After $24 \mathrm{~h}$, the medium was replaced and the cells incubated for 6,12 and $18 \mathrm{~h}$ in the presence of tested gold complexes.

Cell monolayers were washed twice with cold PBS and harvested. Samples were subjected to three freezing/thawing cycles at $-80^{\circ} \mathrm{C}$, and then vigorously vortexed. Aliquots were removed for the determination of protein content by the Lowry assay [19]. The samples were added of $5 \mathrm{~mL} \mathrm{65 \%} \mathrm{nitric} \mathrm{acid} \mathrm{and} \mathrm{transferred}$ into a microwave teflon vessel. Subsequently, samples were digested using a speed wave MWS-3 Berghof instrument (Eningen, Germany). After cooling, each mineralized sample was poured into a plastic vial and diluted to $10 \mathrm{~mL}$ with ultra pure water. The determinations of gold were performed by using an axial ICP-OES Liberty, Series II, Varian (Palo Alto, CA, USA), at the wavelength $242.795 \mathrm{~nm}$. The calibration curve was obtained using known concentrations of standard solutions purchased by Sigma-Aldrich.

\subsection{Enzyme inhibition}

2.3.1. Isolation and purification of thioredoxin reductases from rat liver cytosol and mitochondria. Highly purified cytosolic thioredoxin reductase (TrxR1) was prepared according to Luthman and Holmgren [20] starting from rat liver cytosol obtained after centrifugation of the liver homogenate at 45,000g for $1 \mathrm{~h}$. Mitochondrial thioredoxin reductase (TrxR2) was purified from liver mitochondria following the procedure of Rigobello et al. [21]. After affinity chromatography (2', 5'-ADP-sepharose), the enzymes were further purified by chromatography through a $\omega$-aminohexyl-sepharose $4 \mathrm{~B}$ column. Briefly, the fractions obtained after the affinity chromatography step were concentrated by ultrafiltration and than applied on a $\omega$-aminohexyl-sepharose 4B column equilibrated with $50 \mathrm{mM}$ Tris- $\mathrm{HCl}$ buffer ( $\mathrm{pH} 7.5)$ and the enzymatic fraction was eluted with a linear gradient of $\mathrm{NaCl}$ (from 0.0 to $0.8 \mathrm{M}$ ). The enzyme showed a unique band on SDS-PAGE. 
2.3.2. In vitro TrxR1 and TrxR2 inhibition. The assay was performed in $0.2 \mathrm{M} \mathrm{Na}, \mathrm{K}-\mathrm{phosphate}$ buffer $(\mathrm{pH}$ 7.4) containing $2 \mathrm{mM}$ EDTA, $0.25 \mathrm{mM}$ NADPH and about $0.5-2 \mu \mathrm{g}$ of TrxR protein. The reaction was initiated by the addition of $3 \mathrm{mM}$ DTNB (5,5'-dithiobis (2-nitrobenzoic acid)) to both sample and reference and the increase of absorbance was monitored at $412 \mathrm{~nm}$ over $5 \mathrm{~min}$ at $25^{\circ} \mathrm{C}$. Enzyme activity was calculated taking into account that 1 mole of NADPH yields 2 moles of CNTP anion (reduced DTNB).

2.3.3. In vitro GR inhibition. Glutathione reductase activity was estimated at $25^{\circ} \mathrm{C}$ in $0.1 \mathrm{M}$ Tris/ $\mathrm{HCl}(\mathrm{pH}$ 8.1) containing $0.2 \mathrm{mM}$ NADPH. Reactions were started by the addition of $1 \mathrm{mM}$ GSSG and followed spectrophotometrically at $340 \mathrm{~nm}$.

2.3.4. In vitro GPx inhibition. Glutathione peroxidase activity was estimated at $25^{\circ} \mathrm{C}$ in $50 \mathrm{mM}$ Hepes/Tris (pH 7.0) and EDTA $3 \mathrm{mM}, 0.3 \mathrm{mM}$ NADPH, $5 \mathrm{mM}$ GSH and $0.25 \mathrm{mM}$ tert-butyl hydroperoxide according to Little et al. [22].

2.3.5. Inhibition of redox enzymes by gold(I) complexes in cells. 2008 cells were grown in $75 \mathrm{~cm}^{2}$ flasks at confluence and treated with gold complexes at concentrations corresponding to $\mathrm{IC}_{50}$ values for $18 \mathrm{~h}$. At the end of incubation time, cells were collected, washed with PBS and centrifuged. Each sample was then lysed with RIPA buffer modified as follows: $150 \mathrm{mM} \mathrm{NaCl}, 50 \mathrm{mM}$ Tris-HCl, $1 \%$ Triton $\mathrm{X}-100,1 \%$ SDS, $1 \%$ DOC, 1 $\mathrm{mM} \mathrm{NaF}, 1 \mathrm{mM}$ EDTA, and immediately before use, an anti-protease cocktail (Roche, Basel, Switzerland) containing PMSF was added supplemented with protease inhibitors. Samples were tested for thioredoxin reductase $(0.080 \mathrm{mg}$ proteins $)$, glutathione reductase $(0.080 \mathrm{mg}$ proteins $)$ and glutathione peroxidase $(0.5 \mathrm{mg}$ proteins) activities as above described.

\subsection{Apoptosis studies}


2.4.1. Caspase-3 activation. Caspase-3 activity was detected by using the ApoAlert Caspase-3 Fluorescent

Assay Kit (Clontech, Mountain View, CA, USA) according to the manufacturer's recommended procedures.

2008 cells $\left(1 \cdot 10^{6}\right)$ were collected after $12 \mathrm{~h}$ of incubation in the presence of tested compounds (at concentrations corresponding to $\mathrm{IC}_{50}$ values) and lysed on ice in $50 \mu \mathrm{L}$ of lysis buffer for $10 \mathrm{~min}$, then treated with $50 \mu \mathrm{L}$ of reaction buffer containing dithiothreitol (DTT) and $5 \mu \mathrm{L}$ of caspase-3 substrate solution (Asp-Glu-Val-Asp-7amino-4-trifluoromethyl-coumarin [DEVD-AFC], Clontech). The fluorescence was determined with a PerkinElmer 550 spectrofluorometer (excitation $440 \mathrm{~nm}$, emission $505 \mathrm{~nm}$ ). The caspase-3 activity was expressed as the increase of the AFC-emitted fluorescence.

2.4.2. Nuclear DNA fragmentation. 2008 or $\mathrm{C} 13^{*}$ cells $\left(10^{4}\right.$ per well) were treated in a 96 -well plate at $37^{\circ} \mathrm{C}$ for $24 \mathrm{~h}$ with $\mathrm{IC}_{50}$ concentration of tested compounds, $1.5 \mu \mathrm{M}$ auranofin and $25 \mu \mathrm{M}$ cisplatin. Afterwards, the plate was centrifuged for $10 \mathrm{~min}$, the supernatant removed, and the pellet treated according to the manufacturer's instructions of the ELISA ${ }^{\text {plus }}$ cell death detection kit (Roche). The extent of nuclear fragmentation was measured in a plate reader following absorbance at 405 minus $492 \mathrm{~nm}$.

2.4.3. DAPI and Hoechst 33342 staining. 2008 cells were seeded into 8-well tissue-culture slides (BD Falcon, Bedford, MA, USA) at $5 \cdot 10^{4}$ cells/well $\left(0.8 \mathrm{~cm}^{2}\right)$. After $24 \mathrm{~h}$, cells were washed twice with PBS and following $24 \mathrm{~h}$ of treatment with $\mathrm{IC}_{50}$ concentration of tested complexes cells were fixed in $4 \%$ freshly prepared, ice-cold paraformaldehyde, postfixed in ethanol and air-dried. Slides were then stained for 5 min with $5 \mu \mathrm{g} / \mathrm{mL}$ 4,6-diamidino-2-phenylindole (DAPI, Sigma-Aldrich,) or $1 \mathrm{mg} / \mathrm{mL}$ Hoechst (Sigma-Aldrich,) in PBS before being examined by fluorescence microscopy (Olympus BX41, Cell F software, Olympus, Munster, Germany).

\subsection{Reactive oxygen species (ROS) production}

The production of ROS was measured in 2008 cells $\left(10^{4}\right.$ per well) grown for $24 \mathrm{~h}$ in a 96-well plate in RPMI 1640 without phenol red. Cells were then washed in PBS/10 mM glucose and loaded with $10 \mu \mathrm{M} 2^{\prime}, 7^{\prime}-$ 
1 dichlorodihydrofluorescein diacetate ( $\mathrm{H}_{2}$-DCFDA) (Molecular Probes-Invitrogen, Eugene, OR) for $20 \mathrm{~min}$, in 2

4 the dark. Afterwards, the cells were washed with the same medium and incubated with $\mathrm{IC}_{50}$ concentration of 5

6 tested compounds. Fluorescence increase of DCFDA was estimated utilizing the wavelengths of $485 \mathrm{~nm}$ 7

(excitation) and $527 \mathrm{~nm}$ (emission) in a Fluoroskan Ascent FL (Labsystem, Finland) plate reader. Antimycin (3

$\mu \mathrm{M}$, Sigma), a potent inhibitor of Complex III in the electron transport chain, was used as positive control.

Drug-induced cell cycle effects and DNA fragmentation were analysed by flow cytometry after DNA staining with propidium iodide (PI) according to Nicoletti et al. [23]. Briefly, 2008 cells $\left(5 \cdot 10^{5}\right.$ cells) were exposed for 1-24 $\mathrm{h}$ to tested compound concentrations corresponding to $\mathrm{IC}_{50}$ values. PI solution ( $\left.1 \mathrm{~mL}\right)$ containing $50 \mu \mathrm{g} / \mathrm{mL}$ of PI, $0.1 \% \mathrm{~m} / \mathrm{v}$ of Triton X-100 and $0.01 \% \mathrm{~m} / \mathrm{v}$ of sodium citrate, was added to cells and then incubated for 25 minutes at $4{ }^{\circ} \mathrm{C}$ in the dark. Induced cell death was determined as percentage of hypodiploid nuclei counted over the total cell population measured by FACScalibur flow cytometer (BectonDickinson, CA, USA) using a 550-600 nm filter. Analysis was performed by Cell Quest software (BectonDickinson).

\subsection{Statistical analysis}

All the values are the means \pm SD of not less than five measurements. Multiple comparisons were made by one-way analysis of variance followed by Tukey-Kramer multiple comparison test or ANOVA test $(* * * \mathrm{p}<0.001 ; * * \mathrm{p}<0.01 ; * \mathrm{p}<0.05)$. 
 \\ 3. Results}

\subsection{Synthesis of phosphine gold(I) complexes}

Phosphine gold(I) complexes were prepared according to the literature procedures as outlined in Figure 1. The commercially available complex $\left[\mathrm{AuCl}\left(\mathrm{PEt}_{3}\right)\right](1)$ was utilized as the precursor of gold(I) compounds which were obtained by replacing directly, or via the aquo derivative, the labile chloride group. By reactions with the pertinent salt $(\mathrm{NaBr}, \mathrm{KCN}$ and $\mathrm{KSCN})$ in aqueous solutions, the aquo intermediate species gave the corresponding neutral bromo, (2) cyano (3) and thiocyanato (4) complexes [10], respectively. Direct mixing of $\left[\mathrm{AuCl}\left(\mathrm{PEt}_{3}\right)\right]$ and sodium diethyldithiocarbamate (Nadedc) or potassium xanthate (Kxant) in ethanol/water solutions afforded neutral $\left[\mathrm{Au}(\mathrm{dedc})\left(\mathrm{PEt}_{3}\right)\right](\mathbf{5})$ and $\left[\mathrm{Au}(\mathrm{xant})\left(\mathrm{PEt}_{3}\right)\right](\mathbf{6})$ complexes [11], whereas mixing with

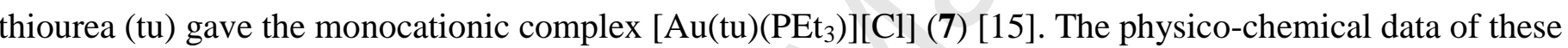
compounds correlate well with the analytical data of the corresponding complexes reported in the literature.

For comparison purposes, Table 1 shows selected X-ray parameters and ${ }^{31} \mathrm{P}$ NMR chemical shifts of the triethylphosphine gold(I) compounds utilised in our study. X-ray data taken from the literature confirm that the molecular structure of all of these complexes adopts a near-linear arrangement (P-Au-X angle in the narrow $173.6-178.7^{\circ}$ window). The Au-P distance is a little affected by the nature of the trans-coordinated atom, being restricted in the 2.245-2.265 $\AA$ range in the case of trans-S donors, and slightly lengthened at $2.288 \AA$ by the cyano group [24]. On the other side, the Au-S distance lengthens from $2.293 \AA$ in Auranofin [24] to $2.337 \AA$ in the dedc derivative [25], suggesting that the metal S-thioglucose bond may be considered stronger than the metal S-dithiocarbamate bond. The analysis of NMR data establishes that coordination of $\mathrm{PEt}_{3}$ to $\mathrm{Au}(\mathrm{I})$ induces a significant downfield shift of the ${ }^{31} \mathrm{P}$ signal from $-17.8 \mathrm{ppm}$ in uncoordinated $\mathrm{PEt}_{3}$ to ca. $35 \pm 3 \mathrm{ppm}$ in the gold complexes pointing toward a strong metal phosphine interaction. The larger downfield shift is observed for Auranofin, suggesting that this complex has the strongest metal-P bond in the series. 


\subsection{Cytotoxicity Studies}

Gold(I) complexes and the corresponding uncoordinated ligands were examined for their cytotoxic properties against a panel of human tumor cell lines including lung (A549), colon (HCT-15), breast (MCF-7) and cervical (HeLa) cancers along with leukemia (HL60) and melanoma (A375). Under the same experimental conditions, cisplatin and auranofin were also evaluated, the former as the most widely used anticancer metallodrug and the latter as the reference phosphine gold(I) compound. $\mathrm{IC}_{50}$ values, calculated from the dosesurvival curves obtained after $72 \mathrm{~h}$ of drug treatment from the MTT test, are shown in Table 2. Uncoordinated ligands proved to be quite ineffective against all tumor cell lines (data not shown). Although the $\left[\mathrm{Au}(\mathrm{tu})\left(\mathrm{PEt}_{3}\right)\right][\mathrm{Cl}]$ complex showed a cytotoxic potency higher than that of cisplatin, it proved to be roughly 5 times less effective than auranofin in decreasing cell viability over 6 cancer cell types. $\left[\mathrm{Au}(\mathrm{dedc})\left(\mathrm{PEt}_{3}\right)\right]$, $\left[\mathrm{AuCl}\left(\mathrm{PEt}_{3}\right)\right]$ and $\left[\mathrm{AuBr}\left(\mathrm{PEt}_{3}\right)\right]$ complexes showed a cytotoxic activity in the sub-micromolar range against all cancer cell lines, with $\mathrm{IC}_{50}$ average values from about 15 - to 20 -fold lower than those obtained with cisplatin and comparable with those exhibited by the phosphine gold(I) reference drug. The most effective compounds were $\left[\mathrm{Au}(\mathrm{xant})\left(\mathrm{PEt}_{3}\right)\right],\left[\mathrm{Au}(\mathrm{CN})\left(\mathrm{PEt}_{3}\right)\right]$ and $\left[\mathrm{Au}(\mathrm{SCN})\left(\mathrm{PEt}_{3}\right)\right]$. Xanthogenate, cyanate and thiocyanate gold(I) complexes showed $\mathrm{IC}_{50}$ average values of about 80 and 2 times lower than that of cisplatin and auranofin, respectively. Interestingly, they appeared efficient against human non-small lung A549 and colon HCT-15 cancer cells, notoriously poorly sensitive to cisplatin, thus reflecting their ability to overcome intrinsic cisplatin 
resistance. Moreover, classical clonogenic assays were performed in 2008 human ovarian cancer cells exposed to tested compounds and results were found very consistent with data obtained with MTT test (data not shown).

The encouraging results obtained against the in-house panel of cell lines prompted us to test the cytotoxic activity of these gold(I) complexes onto three additional cell line pairs, two of which (2008/C13* human ovarian cancer cells and A431/A431-Pt human cervix carcinoma cells) had been in vitro selected for their resistance to cisplatin and two (U1285/U1285dox human lung cancer cells and LoVo/LoVoMDR human colon adenocarcinoma cells) selected for their resistance to doxorubicin, thus retaining the MDR phenotype. Although cisplatin resistance is multifactorial, the main molecular mechanisms involved in C13* and A431-Pt cell resistance have almost been defined. In particular, in human ovarian cancer $\mathrm{C} 13^{*}$ cells, resistance is correlated to reduced cellular drug uptake, high cellular glutathione and thioredoxin reductase levels [9], and enhanced repair of DNA damage [27]. In human squamous cervical carcinoma A431-Pt cells, resistance is due to defect in drug uptake and to decreased levels of proteins involved in DNA mismatch repair (MSH2), causing an increased tolerance to cisplatin-induced DNA damage [28]. Cytotoxicity of tested compounds in cisplatin sensitive and resistant cells was assessed after a 48-h drug exposure by the MTT test (Table 3). Cross-resistance profiles were evaluated by means of the resistance factor $(\mathrm{RF})$, which is defined as the ratio between $\mathrm{IC}_{50}$ values calculated for the resistant cells and those arising from the sensitive ones. All the tested gold(I) complexes, as well as auranofin, exhibited a different cross-resistance profile than that of cisplatin. RF values calculated for all gold(I) complexes were about 2 and 10 times lower than those calculated for cisplatin against human cervix and ovarian cancer cell line pairs, respectively. These results attesting their ability to overcome resistance in both cisplatin phenotypes (C13* and A431/Pt) strongly support the hypothesis of a different pathway of action of these gold(I) complexes from that of cisplatin. Table 3 also reports data obtained in RH4 cisplatin-revertant cells, a cisplatinsensitive cell line obtained from $\mathrm{C} 13 *$ subline after reverting cisplatin resistance [29]. RH4 revertant cells have been isolated from $\mathrm{C} 13^{*}$ cells by selection with the lipophilic cation rhodamine123. The RH4 cells lost a substantial portion of their cisplatin resistance, being only 2- to 3-fold resistant to cisplatin. Despite this major loss of resistance, they retained a number of the phenotypic features related to cisplatin resistance, observed in C13* cells [29]. As a whole, against RH4 cells, the behavior of all gold complexes was comparable to that 
1 elicited in the cisplatin sensitive 2008 cell line, even if $\mathrm{Au}(\mathrm{SCN}) \mathrm{PEt}_{3}$ emerged as the most efficient in inhibiting

2

3 RH4 cell growth.

5

6

7

Acquired multidrug resistance (MDR), whereby cells become refractory to multiple drugs, poses a very important challenge to the success of anticancer chemotherapy. The resistance of U1285dox cells to doxorubicin, a drug belonging to the MDR spectrum, is an atypical multidrug-resistance characterised by the absence of the P-glycoprotein (P-gp) overexpression as well as by the overexpression of MRP1 [30]. Recently, in U1285dox cells, the basal level of active TrxR has been found significantly higher (1.5-fold) than in the drug sensitive U1285 cells [17]. On the contrary, in LoVo/MDR cells, resistance to doxorubicin is associated with an overexpression of the multispecific drug transporters, such as the $170 \mathrm{kDa}$ P-glycoprotein [31]. Cytotoxicity of tested compounds in wild-type and MDR strain cells was assessed after a $48 \mathrm{~h}$ drug exposure by the MTT test (Table 4). The calculation of an RF average value from about 35 to 88 times lower than that obtained with doxorubicin, in U1285dox and LoVo/MDR, respectively, clearly suggests that gold(I) complexes are not potential MDR substrates. $\left[\mathrm{Au}(\mathrm{xant})\left(\mathrm{PEt}_{3}\right)\right],\left[\mathrm{Au}(\mathrm{CN})\left(\mathrm{PEt}_{3}\right)\right]$ and $\left[\mathrm{Au}(\mathrm{SCN})\left(\mathrm{PEt}_{3}\right)\right]$ were particularly powerful in decreasing viability of both resistant phenotypes.

\subsection{Inhibition of purified thioredoxin reductase, glutathione peroxidase and glutathione reductase}

The inhibitory effects of gold(I) complexes toward cytosolic or mitochondrial isoforms of isolated rat TrxR were measured according to the current procedures [20]. Gold(I) complexes were tested at increasing concentrations and $\mathrm{IC}_{50}$ values were calculated from the dose-effect curves (Table 5). The cytosolic isoform appeared markedly inhibited by all gold(I) derivatives at nanomolar concentrations. Some complexes such as $\left[\mathrm{Au}(\mathrm{xant})\left(\mathrm{PEt}_{3}\right)\right]$ and $\left[\mathrm{Au}(\mathrm{dedc})\left(\mathrm{PEt}_{3}\right)\right]$ exhibited $\mathrm{IC}_{50}$ values lower than that determined after auranofin treatment whereas $\left[\mathrm{Au}(\mathrm{CN})\left(\mathrm{PEt}_{3}\right)\right]$ and $\left[\mathrm{Au}(\mathrm{tu})\left(\mathrm{PEt}_{3}\right)\right][\mathrm{Cl}]$ showed an inhibitory potency similar to that observed for auranofin. The $\mathrm{IC}_{50}$ values calculated for $\left[\mathrm{AuCl}\left(\mathrm{PEt}_{3}\right)\right],\left[\mathrm{Au}(\mathrm{SCN})\left(\mathrm{PEt}_{3}\right)\right]$ and $\left[\mathrm{AuBr}\left(\mathrm{PEt}_{3}\right)\right]$ appeared slightly lower than those determined for auranofin. 
Mitochondrial thioredoxin reductase appeared less sensitive to the inhibitory effect promoted by the tested complexes and higher concentrations were required for a reduction of 50\% of TrxR2 activity (Table 5).

Moreover, the $\mathrm{IC}_{50}$ values obtained with all gold(I) derivatives were higher than that obtained with auranofin, excluding those calculated for $\left[\mathrm{Au}(\mathrm{xant})\left(\mathrm{PEt}_{3}\right)\right]$ and $\left[\mathrm{Au}(\mathrm{dedc})\left(\mathrm{PEt}_{3}\right)\right]$. The difference in sensitivity to gold derivatives is a common feature of the two thioredoxin reductases and possibly depends on the different sequence of the two isoforms and the greater acidity of cytosolic thioredoxin reductase [32].

With the aim of attesting the selectivity of phosphine gold(I) compounds toward thioredoxin reductase isoenzymes, we had also performed glutathione reductase and peroxidase inhibition tests. $\mathrm{IC}_{50}$ values were calculated from the dose-effect curves obtained testing gold(I) complexes within the 1-100 $\mu \mathrm{M}$ range (Table 5). $\left[\mathrm{Au}(\mathrm{tu})\left(\mathrm{PEt}_{3}\right)\right][\mathrm{Cl}]$ appeared the most active in reducing Gpx activity, while $\left[\mathrm{Au}(\mathrm{SCN})\left(\mathrm{PEt}_{3}\right)\right]$ markedly inhibited glutathione reductase. However, glutathione reductase and glutathione peroxidase were affected by all complexes in the micromolar range of concentration, i. e. three orders of magnitude higher than those required for TrxR inhibition. These results clearly suggest that these complexes preferentially inhibit thioredoxin reductase over the other redox enzymes.

\subsection{Effects of gold(I) complexes on redox enzymes in human ovarian cancer cells}

TrxR inhibition was also evaluated in 2008 cells treated for $18 \mathrm{~h}$ with $\mathrm{IC}_{50}$ concentrations of gold(I) complexes. As illustrated in Fig. 2A, all tested complexes showed $\mathrm{IC}_{50}$ values comparable with that obtained with auranofin; $\left[\mathrm{Au}(\mathrm{CN})\left(\mathrm{PEt}_{3}\right)\right],\left[\mathrm{Au}(\mathrm{SCN})\left(\mathrm{PEt}_{3}\right)\right]$ and $\left[\mathrm{AuBr}\left(\mathrm{PEt}_{3}\right)\right]$ were the most active derivatives, being able to decrease cellular TrxR activity by approximately 90, 92 and 94\% with respect to untreated cells.

Similarly to the isolated enzymes, also in cultured cells glutathione reductase and peroxidase were inhibited by gold(I) complexes, although far less intensely than thioredoxin reductase. Interestingly, $\left[\mathrm{Au}(\mathrm{tu})\left(\mathrm{PEt}_{3}\right)\right][\mathrm{Cl}]$, a charged gold(I) compound, noticeably inhibited isolated glutathione peroxidase, but it was far less effective in 
1 inhibiting the same enzyme in 2008 cancer cells in line with its scarce permeability to plasmalemma, as shown

3

4 in Fig. 3.

5

6

7

\subsection{Cellular uptake}

In our previous studies we had highlighted the relationship between auranofin cytotoxicity and cellular accumulation [9]. Cellular uptake of phosphine gold(I) complexes was quantified, by means of ICP analysis, in 2008 cells after a continuous treatment with $\mathrm{IC}_{50}$ concentrations lasting 6, 12 and $18 \mathrm{~h}$. Intracellular accumulation was time-dependent and reached the highest levels after $18 \mathrm{~h}$ exposure. Most probably, for longer treatments the detection may be affected by the strong cytotoxicity induced by gold derivatives. As seen in Fig. 3, which reports the results after $18 \mathrm{~h}$ treatment, $\left[\mathrm{Au}(\mathrm{xant})\left(\mathrm{PEt}_{3}\right)\right],\left[\mathrm{Au}(\mathrm{dedc})\left(\mathrm{PEt}_{3}\right)\right],\left[\mathrm{Au}(\mathrm{CN})\left(\mathrm{PEt}_{3}\right)\right]$ and $\left[\mathrm{Au}(\mathrm{SCN})\left(\mathrm{PEt}_{3}\right)\right]$ entered cancer cells with a similar efficiency to auranofin, whereas $\left[\mathrm{AuBr}\left(\mathrm{PEt}_{3}\right)\right]$ and $\left[\mathrm{AuCl}\left(\mathrm{PEt}_{3}\right)\right]$ cellular uptake was found roughly 2-fold lower. Conversely, $\left[\mathrm{Au}(\mathrm{tu})\left(\mathrm{PEt}_{3}\right)\right][\mathrm{Cl}]$ seemed to hardly cross cellular plasmalemma giving rise to a cellular gold amount of about 4 times lower compared with the reference gold(I) compound. Clearly, the degree of uptake of all gold(I) derivatives correlates well with the cytotoxicity data.

\subsection{ROS production}

It is well-known that mitochondria can generate hydrogen peroxide [33] and, thus, play a crucial role in the apoptotic process [34]. Moreover, it has been previously shown that TrxR inhibition alters cell conditions, as the increase of hydrogen peroxide concentration due to the prevention of its removal causes an inbalance in cell redox conditions, thus leading to mitochondrial membrane permeabilization and swelling [35,36]. On this basis, we thought it of interest to measure the modification of $\mathrm{H}_{2} \mathrm{O}_{2}$ basal production in 2008 cancer cells treated with $\mathrm{IC}_{50}$ concentrations of gold(I) complexes by using the peroxide-sensitive fluorescent probe CM-DCFDA (Fig. 4). Antimycin, a classic inhibitor of the mitochondrial respiratory chain at the level of complex III, used as a 
positive control, was able to stimulate the production of hydrogen peroxide. All the compounds were able to increase the hydrogen peroxide basal production at a level similar $\left(\left[\mathrm{AuBr}\left(\mathrm{PEt}_{3}\right)\right],\left[\mathrm{Au}(\mathrm{tu})\left(\mathrm{PEt}_{3}\right)\right][\mathrm{Cl}]\right.$, $\left.\left[\mathrm{Au}(\mathrm{dedc})\left(\mathrm{PEt}_{3}\right)\right]\right)$ or higher $\left(\left[\mathrm{Au}(\mathrm{CN})\left(\mathrm{PEt}_{3}\right)\right],\left[\mathrm{Au}(\mathrm{SCN})\left(\mathrm{PEt}_{3}\right)\right],\left[\mathrm{AuCl}\left(\mathrm{PEt}_{3}\right)\right]\right.$ and $\left.\left[\mathrm{Au}(\mathrm{xant})\left(\mathrm{PEt}_{3}\right)\right]\right)$ than that elicited by antimycin.

\subsection{Apoptosis and cell cycle studies}

It has been previously reported that auranofin and other gold(I) derivatives induce apoptosis in cancer cells through the activation of caspases [37,38]. As caspase-3 is a well-known executor enzyme in apoptosis pathway [39], we have investigated the ability of gold(I) derivatives to activate caspase- 3 in 2008 cells treated for $12 \mathrm{~h}$ with $\mathrm{IC}_{50}$ concentrations of these compounds. Fig. 5 A shows that all derivatives markedly stimulated caspase-3 activity with respect to the control. The most active compounds were the gold(I) complexes bearing the cyanate, thiocyanate and xanthogenate ligands, with an apoptosis induction about 1.2, 1.4 and 1.6 times greater with respect to that induced by auranofin treatment, respectively. On the contrary, $\left[\mathrm{Au}(\mathrm{tu})\left(\mathrm{PEt}_{3}\right)\right][\mathrm{Cl}]$ was the less effective, with a caspase- 3 activation roughly 2 times lower compared to that exerted by auranofin.

Nuclear DNA fragmentation and apoptosome complex formation are critical steps in the apoptotic process [40]. DNA fragmentation tests performed on 2008 cells treated for $24 \mathrm{~h}$ with $\mathrm{IC}_{50}$ concentrations showed the ability of all gold(I) derivatives to increase mono- and oligo-nucleosome formation, although to a different extent (Fig. 5 B). In particular, [Au(xant)( $\left.\left.\mathrm{PEt}_{3}\right)\right]$ appeared the most efficient in inducing DNA fragmentation, being able to increase about three times nucleosome formation. $\left.\left[\mathrm{Au}(\mathrm{tu}) \mathrm{PEt}_{3}\right)\right][\mathrm{Cl}]$ and $\left[\mathrm{AuCl}\left(\mathrm{PEt}_{3}\right)\right]$ were the less effective, with a DNA fragmentation about 3 and 10 times lower compared to that exerted by auranofin, respectively.

Figure $5 \mathrm{C}$ shows Hoechst 33342 and DAPI stained 2008 cells after $24 \mathrm{~h}$ treatment with $\mathrm{IC}_{50}$ concentrations of $\left[\mathrm{Au}(\mathrm{xant})\left(\mathrm{PEt}_{3}\right)\right]$. Treated cells as compared with untreated cells, displayed chromatin condensation and fragmentation characteristics, typical features of apoptosis. 
Apoptotic cell death induction was confirmed through a time dipendent cell cycle analysis performed by FACS. Fig. 6 reports cell cycle profiles of 2008 cells treated for $24 \mathrm{~h}$ with $\mathrm{IC}_{50}$ concentrations of $\left[\mathrm{Au}(\mathrm{CN})\left(\mathrm{PEt}_{3}\right)\right],\left[\mathrm{Au}(\mathrm{SCN})\left(\mathrm{PEt}_{3}\right)\right]$ and $\left[\mathrm{Au}(\mathrm{xant})\left(\mathrm{PEt}_{3}\right)\right]$ that distinguished themselves as the most effective compounds, being able to increase sub-G1 cell population of about 6,11 and 14 times with respect to control cells. However, a slight accumulation of 2008 cells in G2/M phase was observed after treatment with all tested gold(I) complexes.

\section{Discussion}

The Trx system, which includes NADPH, thioredoxin reductase (TrxR), and Trx, participates in several cell processes including reduction of protein disulfides, removal of hydrogen peroxide through peroxiredoxins, formation of deoxyribonucleotides mediated by ribonucleotide reductase, and regulation of transcription factors [41]. TrxR has recently emerged as a new exciting anti-cancer target since it is overexpressed in various aggressive tumors and may contribute to drug resistance. Indeed, expression level of TrxR correlates well with the resistance of several human tumor cells to cisplatin, doxorubicin, adriamycin and other chemotherapeutics $[42,43]$. TrxR is endowed with a flexible C-terminal extension containing a cysteine/selenocysteine redox center [44] that can easily interact with different and chemically unrelated substrates and inhibitors. Most of the recognized inhibitors of thioredoxin reductase are electrophilic compounds interacting at the level of the $\mathrm{SH} / \mathrm{Se}^{-}$ motif of the C-terminal portion of the enzyme [45]. Previous research has shown that gold(I) compounds readily react with physiological thiols forming relatively stable thiol gold(I) adducts [46]. However, the various cellular thiols exhibit a different reactivity depending on steric factors and, primarily, on their acidity, as apparent from the $\mathrm{pH}$ dependency [47]. Consequently, to explain the reactivity and cellular distribution of triethylphosphine gold(I) compounds, a sequential thiol exchange mechanism has been proposed [48]. According to this mechanism, membrane sulfhydryl groups exert a shuttling action of the gold-triethylphosphine moiety to the cytosolic sulfhydryl groups. Thiolates are known to act as 'soft' ligands forming covalent bonds with the 'soft' 
1

gold(I) ion; corresponding selenolates are 'softer' donor ligands compared to thiolates and, consequently, behave as better substrates for the gold(I) ion [49-51]. This enhanced affinity of the gold(I) ion for selenolates makes the selenocysteine group present in a well accessible $\mathrm{C}$-terminal arm of thioredoxin reductase, a primary selective target of gold (I) compounds. Gold(I) complexes are linear complexes characterized by a monocationic gold ion coordinated by two ligands (usually a neutral along with a mononegative ligand).

In our $\left[\mathrm{Au}(\mathrm{X})\left(\mathrm{PEt}_{3}\right)\right]$-type complexes, the triethylphosphine ligand was retained for all the compounds, as $\left[\mathrm{Au}\left(\mathrm{PEt}_{3}\right)\right]^{+}$moiety has been found critical to achieve a significant in vitro antitumor activity [12]. The (X) group was selected (Scheme 1) among a series of ligands possessing different binding strength to gold in order to investigate a possible structure-activity relationship based on the different lability of the Au-(X) bond. In fact, the lability of the thiolate group may play a crucial role in the biodistribution and kinetic properties of this class of metal complexes. Consequently, a different degree of reactivity with both physiological thiolates and/or selenolate groups could be envisaged depending on the various (X) ligands utilized. In order to correlate the influence of the variable ligands $(\mathrm{X})$ in our compounds to the different effects observed we may tentatively refer to the softness-hardness principle [52]. The latter suggests that hard acids preferentially associate with hard bases, while soft acids prefer to combine with soft bases. The halogens $\mathrm{Cl}$ and $\mathrm{Br}$ are a hard base and a borderline hard/soft base, respectively and consequently show scarce preference for the soft acid $\mathrm{Au}(\mathrm{I})$. As matter of fact $\left[\mathrm{AuCl}\left(\mathrm{PEt}_{3}\right)\right]$ and $\left[\mathrm{AuBr}\left(\mathrm{PEt}_{3}\right)\right]$ derivatives are the less active both in inhibiting thioredoxin reductases (Table 5) and in penetrating into the cell (Fig. 5). All the other ligands are soft bases, which exhibit high preference for the gold(I) center, although to a different extent. In particular, the binding of dithiocarbamate and xanthogenate ligands to gold is strengthened by the mesomeric resonance form. The gold compounds bearing these ligands $\left(\left[\mathrm{Au}(\mathrm{dedc})\left(\mathrm{PEt}_{3}\right)\right]\right.$ and $\left.\left[\mathrm{Au}(\mathrm{xant})\left(\mathrm{PEt}_{3}\right)\right]\right)$ are particularly effective both in inhibiting thioredoxin reductases (Table 5) and in penetrating through cell membranes (Fig. 3). Possibly, these complexes can easily reach the biological target and once there exchange their ligands with the cellular nucleophiles either when entering the cell or when interacting with the selenolate or thiolate groups present at 
1 the active site of thioredoxin reductases. However, also other properties of the ligands, including steric and

2

3

Thiol redox state and cellular hydrogen peroxide levels are controlled not only by thioredoxin system but also by glutathione system which depends on glutathione reductase. Both systems utilize NADPH and remove hydrogen peroxide through the respective peroxidases. Glutathione peroxidase and thioredoxin reductase possess a selenol group at their catalytic site. It has been already described that some phoshine gold(I) compounds are also able to inhibit glutathione peroxidase at very low concentrations [37]. In vitro studies on the interaction with TrxR, GR and GPx showed that all phosphine gold complexes, as already stated for a variety of gold compounds, mostly inhibit cytosolic and mitochondrial TrxR enzyme isoforms while GR and GPx required higher concentrations to be inhibited. In this context, previous studies established that the rate of enzyme inhibition may depend either on the structure of the active site or on the lability of the gold-ligand bond [53]. In previous studies we have compared the cellular response of human ovarian cancer cells to auranofin with that evoked by cisplatin, the first line drug against ovarian cancer [9]. Auranofin, acting as a potent TrxR inhibitor, determined an alteration of the cellular redox state leading to an oxidation of the components of the Trx system thus triggering apoptosis [54]. In human ovarian cancer cells phosphine gold(I) derivatives markedly

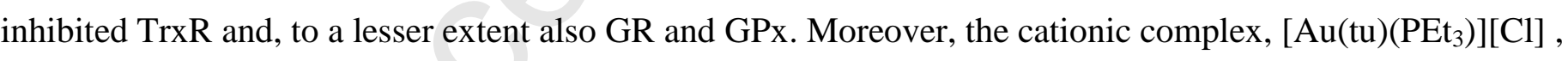
appeared less effective in inhibiting enzyme activity confirming its reduced bioactivity observed in cytotoxicity as well in apoptosis induction experiments. This behaviour could be related to the charged nature of this species that may hinder its ability to cross the cell membrane by passive diffusion. ICP measurements of cellular gold accumulation (Fig. 3) are consistent with this hypothesis. Furthermore, uptake experiments gave important information concerning the essential role of the (X) ligand in facilitating cellular internalization. In fact, gold(I) complexes bearing the most lipophilic xant and dedc ligands, as well as those complexes involving a metal-X covalent bond (complexes 3-6 and 8) entered cells roughly 2 times more efficiently than the halogenated gold compounds (complexes $\mathbf{1}$ and $\mathbf{2}$ ), that are characterised by a partial ionic interaction between the metal and 
1 halogen. In conclusion, neutral and lipophilic gold(I) compounds are internalised more efficiently than charged 2 gold(I) compounds. Coherently, cytotoxicity studies highlighted neutral $\left[\mathrm{Au}(\mathrm{xant})\left(\mathrm{PEt}_{3}\right)\right],\left[\mathrm{Au}(\mathrm{CN})\left(\mathrm{PEt}_{3}\right)\right]$ and $\left[\mathrm{Au}(\mathrm{SCN})\left(\mathrm{PEt}_{3}\right)\right]$ as the most powerful derivatives. In a parallel study, by considering the cytotoxic profiles of a series of linear alkylphosphine and arylphosphine gold(I) dithiocarbamate and xanthate compounds, de Vos et al. demonstrated that they possess a greater cytotoxicity than cisplatin, xanthate derivatives being less active than dithiocarbamate ones [11]. Similarly, our tested xant and dedc complexes showed a significant cytotoxic efficiency, although the xanthate derivative was found to be more efficient than the dithiocarbamate counterpart. In this field, other studies [55] indicated that xanthate complexes of several metals, including gold, palladium and bismuth, are endowed with a high antitumor activity. It has also to be considered that xanthate ligands are reported to be, in general, less toxic than dithiocarbamate ligands [11]. Interestingly, some members of the xanthate family such as tricyclododecan-9-yl-xanthogenate showed selective cytotoxicity towards tumor cells and favor apoptosis by inhibiting sphingosine kinase [56]. Our studies have demonstrated that $\left[\mathrm{Au}(\mathrm{xant})\left(\mathrm{PEt}_{3}\right)\right]$ strongly decreased cancer cell viability inducing a massive apoptosis. The marked inhibition of TrxR leads to the generation of superoxide anion radicals, resulting in an accumulation of intracellular ROS that triggers apoptosis. Moreover, the TrxR inhibition impairs the control of apoptosis signal-regulating kinase 1 (ASK-1) activity exerted by Trx, resulting in the activation of downstream signaling cascades such as MAP kinase apoptotic cell death pathway [57]. In order to characterize the cell death program triggered by tested gold(I) compounds and to correlate TrxR inhibition to apoptosis induction, we have examined some characteristic events of apoptosis in ovarian cancer cells. A close relationships between TrxR inhibition and apoptosis induction has been highlighted with $\left[\mathrm{Au}(\mathrm{SCN})\left(\mathrm{PEt}_{3}\right)\right]$ and $\left[\mathrm{Au}(\mathrm{CN})\left(\mathrm{PEt}_{3}\right)\right]$. Thiocyanate is a physiological ligand having a "soft" character suitable for interaction with gold(I) ions. Serum thiocyanate concentrations are relatively high (from 10 to $100 \mu \mathrm{M}$ ) and increase to the millimolar range in milk, saliva and tears [58,59]. Thiocyanate present in the body fluids derives from dietary sources and from the cyanide detoxification reaction involving thiosulfate and catalyzed by rhodanese. Its affinity for gold(I) would also depend on the presence of two isomeric forms, as described in the case of $\left[\mathrm{Au}(\mathrm{SCN})\left(\mathrm{PMe}_{3}\right)\right]$ and $\left[\mathrm{Au}(\mathrm{NCS})\left(\mathrm{PMe}_{3}\right)\right]$ contributing to the formation of the complex [60]. Our results showed that $\left[\mathrm{Au}(\mathrm{SCN})\left(\mathrm{PEt}_{3}\right)\right]$ elicited marked cytotoxic properties, 
1 strong inhibitory effects on thioredoxin reductase and also make the cells more prone to apoptosis.

2

3

$\left[\mathrm{Au}(\mathrm{SCN})\left(\mathrm{PEt}_{3}\right)\right]$ provides a molecule where the small $\mathrm{NCS}^{-}$ligand can be easily displaced by the $\mathrm{S}^{-} / \mathrm{Se}^{-}$group of thioredoxin reductase, thus explaining the above reported properties.

Recent studies focused on bis-chelate $\mathrm{Au}(\mathrm{I})$ complexes of the ligand 1,3-bis(di-2-pyridylphosphino)propane [38], Au(I) N-heterocyclic carbenes [61] and phosphine Au(I) naphthalimide [62] show that these compounds exhibit selective cytotoxicity towards cancer cells consequent to an efficient inhibition of thioredoxin reductase. In the first study [40] the pyridylphosphino ethane complexes show a low reactivity with protein thiols, while the corresponding analogs containing pyridylphosphino propane ligands show a great tendency to stimulate ligand exchange reactions with thiols indicating that a six-membered chelate ring undergo a more facile ring opening compared to the corresponding five-membered chelates. The peculiar role of phosphine and carbene ligands in gold(I) pro-drugs appears to be under the control of the chemical reactivity of the gold centre $[38,61$ 63]. Moreover, other properties of the ligands such as size, charge, lipophilicity and toxicity determine their biological activity and biodistribution. Finally, in order to be efficient in the biological context, gold(I) complexes should be relatively stable to reach their specific molecular targets, but not too stable to hamper the reaction with the target itself. In linear gold(I) complexes, these properties are permitted and tuned by the accurate choice of the ligands and some of the ligands used in the present work, such as thiocyanate and xanthate, offer interesting perspectives for further studies. In conclusion, these findings clearly validate further investigations for the customization of TrxR inhibition induced by gold(I) complexes with a view to obtain increasingly effective therapeutics able to overcome drug resistance afforded by TrxR overexpression. 


\section{Acknowledgments \\ 2}

3

7

This work was financially supported by University of Padova (Progetto di Ateneo CPDA065113/06),

Ministero dell'Istruzione dell'Università e della Ricerca (PRIN 20078EWK9B) and Swedish Cancer Society (Cancerfonden).

(1)




\section{Figure captions}

Figure 2. Effects of gold(I) complexes on redox enzymes in human ovarian cancer cells. 2008 cells were incubated for $18 \mathrm{~h}$ with $\mathrm{IC}_{50}$ of tested compounds. Subsequently, cells were washed twice with PBS and lysed. Thioredoxin reductase activity was assayed by measuring NADPH- dependent reduction of DTNB at $412 \mathrm{~nm}$ (A); glutathione reductase activity (B) and glutathione peroxidase (C) activities were followed at $340 \mathrm{~nm}$.

Figure 3. Estimation of gold(I) compound uptake in 2008 cells. 2008 cells were incubated for $18 \mathrm{~h}$ with $\mathrm{IC}_{50}$ of tested compounds. Au cellular content was estimated by means of ICP analysis. Results are expressed as ng $\mathrm{Au} / \mathrm{mg}$ of proteins.

Figure 4. Effect of gold(I) compounds on hydrogen peroxide formation in 2008 cells. 2008 cells were preincubated in PBS/10 mM glucose medium for $20 \mathrm{~min}$ at $37^{\circ} \mathrm{C}$ in presence of $10 \mu \mathrm{M} \mathrm{CM}$-DCFDA and then treated with $\mathrm{IC}_{50}$ of gold(I) compounds. Control cells: dashed line. Gold(I) complexes treated cells: continuous line. Antimycin treated cells: dotted line.

\section{Figure 5. Effect of gold(I) compounds on caspase-3 activation (A), nucleosome formation (B) DAPI and}

Hoechst staining (C). 2008 cells were incubated for $12 \mathrm{~h}$ with $\mathrm{IC}_{50}$ of gold(I) compounds and then submitted to the test on caspase-3 induction (A). For DNA fragmentation experiments (B) and DAPI and Hoechst staining (C), 2008 cells were incubated for $24 \mathrm{~h}$ in presence of $\mathrm{IC}_{50}$ of gold(I) compounds. 
1 Figure 6. Cell cycle analysis of 2008 cells treated with gold(I) compounds. 2008 cells were treated with 2

${ }_{4}^{3}$ gold(I) derivatives for $24 \mathrm{~h}$. Cell cycle profiles were analyzed by flow cytometry after DNA staining with 5

6 propidium iodide.

7

8 


\section{References}
1. Gordon DA. In: Kelley WN, Harris ED, Ruddy S, Sledge SB, editors. Textbook of Rheumatology (IV ed.), Philadelphia, WB Saunders company 1989. p. 805-23.

2. Shaw CF III. Gold-based therapeutic agents. Chem Rev 1999;99:2589-2600.

3. Hill DD, Sutton BM. (2,3,4,6-tetra-O-acetyl-1-D-thiopyranosato-S)(triethylphosphine) gold. Cryst Struct Comm 1980;9:679-86.

4. Allen FH. The Cambridge Structural Database: a quarter of a million crystal structures and risingn. Acta Crystallogr 2002 (Sect. B);58:380-8.

5. Coffer MT, Shaw CF III, Eidsness MK, Watkins JW II, Elder RC. Reactions of auranofin and chloro(triethylphosphine)gold with bovine serum albumin. Inorg Chem 1986;25:333-9.

6. Roberts J, Xiao J, Schliesman B, Parsons DJ, Shaw CF III. Kinetics and Mechanism of the Reaction between Serum Albumin and Auranofin (and Its Isopropyl Analogue) in Vitro. Inorg Chem, 1996;35:424-433.

7. Christodoulou J, Sadler PJ, Tucker A. A New Structural Transition of Serum Albumin Dependent on the State of Cys34. Detection by ${ }^{1}$ H-NMR Spectroscopy. Eur J Biochem 1994;225:363-8.

8. Berners-Price SJ, Johnson RK, Mirabelli CK, Faucette LF, McCabe FL, Sadler PJ. Copper(I) complexes with bidentate tertiary phosphine ligands: solution chemistry and antitumor activity. Inorg Chem 1987;26:3383-7.

9. Marzano C, Gandin V, Folda A, Scutari G, Bindoli A, Rigobello MP. Inhibition of thioredoxin reductase by auranofin induces apoptosis in cisplatin-resistant human ovarian cancer cells. Free Radical Biol Med 2007;42:872-81.

10. Talib J, Beck JL, Ralph SF. A mass spectrometric investigation of the binding of gold antiarthritic agents and the metabolite $[\mathrm{Au}(\mathrm{CN})(2)]^{(-)}$to human serum albumin. J Biol Inorg Chem 2006;11:55970. 
11. de Vos D, Ho SY, Tiekink ERT. Cytotoxicity profiles for a series of triorganophosphinegold(I) dithiocarbamates and triorganoposphinegold(I) xanthates. Bioinorg Chem Appl 2004;2:141-54.

12. Tiekink ERT. Phosphinegold(I) thiolates-pharmacological use and potential. Bioinorg Chem Appl 2003;1:3-67.

13. Ronconi L, Marzano $\mathrm{C}$, Zanello $\mathrm{P}$, Corsini M, Miolo G, Maccà $\mathrm{C}$ et al. Gold(III) dithiocarbamate derivatives for the treatment of cancer: solution chemistry, DNA binding, and hemolytic properties. J Med Chem 2006;49:1648-57.

14. El-Etri MM, Scovell WM. Synthesis and spectroscopic characterization of (triethylphosphine)gold(I) complexes $\mathrm{AuX}\left(\mathrm{PEt}_{3}\right)(\mathrm{X}=\mathrm{Cl}, \mathrm{Br}, \mathrm{CN}, \mathrm{SCN}),\left[\mathrm{AuL}\left(\mathrm{PEt}_{3}\right)^{+}\right]\left(\mathrm{L}=\mathrm{SMe}_{2}, \mathrm{SC}\left(\mathrm{NH}_{2}\right)_{2}, \mathrm{H}_{2} \mathrm{O}\right)$, and (.mu.$\mathrm{S})\left[\mathrm{Au}\left(\mathrm{PEt}_{3}\right)\right]_{2 .}$. Inorg Chem 1990;29:480-4.

15. Coates GE, Kowala C, Swan JM. Coordination compounds of group 1B metals I, triethylphosphine complexes of gold(I) mercaptides. Aust J Chem 1966;19:539-45.

16. Sutton BM, McGusty E, Waltz DT, Di Martino MJ. Oral gold. Antiarthritic properties of alkylphosphinegold coordination complexes. J Med Chem 1972;15:1095-8.

17. Björkhem-Bergman L, Jönsson K, Eriksson LC, Olsson JM, Lehmann S, Paul C, Björnstedt M. Drugresistant human lung cancer cells are more sensitive to selenium cytotoxicity. Effects on thioredoxin reductase and glutathione reductase. Biochem Pharmacol 2002;63:1875-84.

18. Alley MC, Scudiero DA, Monks A, Hursey ML, Czerwinski MJ, Fine DL et al. Feasibility of drug screening with panels of human tumor cell lines using a microculture tetrazolium assay. Cancer Res 1988;48:589-601.

19. Lowry OH, Rosebrough NJ, Farr AL, Randall R. Protein measurement with the Folin phenol reagent. J Biol Chem 1951;193:265-75.

20. Luthman M, Holmgren A. Rat liver thioredoxin and thioredoxin reductase: Purification and characterization. Biochemistry 1982;21:6628-33. 
21. Rigobello MP, Callegaro MT, Barzon E, Benetti M, Bindoli A. Purification of mitochondrial thioredoxin reductase and its involvement in the redox regulation of membrane permeability. Free Radic Biol Med 1998;24:370-6.

22. Little C, Olinescu R, Reid KG, O'Brien PJ. Properties and regulation of glutathione peroxidase. J Biol Chem 1970;245:3632-6.

23. Nicoletti I, Migliorati G, Pagliacci MC. A rapid and simple method for measuring thymocyte apoptosis by propidium iodide staining and flow cytometry. J Immunol Methods 1991;139:271-9.

24. Hill DT, Sutton BM. (2,3,4,6-tetra-O-acetyl- $\beta-1-D-t h i o p y r a n o s a t o-S)(t r i e t h y l p h o s p h i n e) g o l d$. Cryst Struct Comm 1980;9:679-86.

25. Ho SY, Tiekink ERT. Crystal structure of (diethyldithiocarbamato) (triethylphosphine) gold(I). Z Krystallogr NCS 2005;220:342-4.

26. Hormann AL, Shaw CF III, Bennett DW, Reiff WM. Solid-state structure and solution equilibria of cyano(triethylphosphine)gold(I). Inorg Chem 1986;25:3953-57.

27. Mamenta EL, Poma EE, Kaufmann WK, Delmastro DA, Grady HL, Chaney SG. Enhanced replicative bypass of platinum-DNA adducts in cisplatin-resistant human ovarian carcinoma cell lines. Cancer Res 1994;54:3500-5.

28. Lanzi C, Perego P, Supino R, Romanelli S, Pensa T, Carenini N et al. Decreased drug accumulation and increased tolerance to DNA damage in tumor cells with a low level of cisplatin resistance. Biochem Pharmacol 1998;55:1247-54.

29. Zinkewich-Peotti K, Andrews PA. Loss of cis-diamminedichloroplatinum(II) resistance in human ovarian carcinoma cells selected for rhodamine 123 resistance. Cancer Res 1992;52:1902-6.

30. Jönsson-Videsäter K, Andersson G, Bergh J, Paul C. Doxorubicin-resistant, MRP1-expressing U1285 cells are sensitive to idarubicin. Ther Drug Monit 2003;25:331-9.

31. Wersinger C, Rebel G, Lelong-Rebel IH. Detailed study of the different taurine uptake systems of colon LoVo MDR and non-MDR cell lines. Amino Acids 2000;19:667-85. 
32. Sun Q-A, Wu Y, Zappacosta F, Jeang K-T, Lee BJ, Hatfield DL et al. Redox regulation of cell signaling by selenocysteine in mammalian thioredoxin reductases. J Biol Chem 1999;274:24530-52.

33. Loschen G, Flohé L, Chance B. Respiratory chain linked $\mathrm{H}(2) \mathrm{O}(2)$ production in pigeon heart mitochondria. FEBS Lett 1971;18:261-4.

34. Finkel T, Holbrook NJ. Oxidants, oxidative stress and the biology of ageing. Nature 2000;408:23947.

35. Rigobello MP, Scutari G, Folda A, Bindoli A. Mitochondrial thioredoxin reductase inhibition by gold(I) compounds and concurrent stimulation of permeability transition and release of cytochrome c. Biochem Pharmacol 2004;67:689-96.

36. Rigobello MP, Scutari G, Boscolo R, Bindoli A. Induction of mitochondrial permeability transition by auranofin, a gold(I)-phosphine derivative. Br J Pharmacol 2002;136:1162-8.

37. Rigobello MP, Folda A, Dani B, Menabò R, Scutari G, Bindoli A. Gold(I) complexes determine apoptosis with limited oxidative stress in Jurkat T cells. Eur J Pharmacol 2008;582:26-34.

38. Rackham O, Nichols SJ, Leedman PJ, Berners-Price SJ, Filipovska A. A gold(I) phosphine complex selectively induces apoptosis in breast cancer cells: implications for anticancer therapeutics targeted to mitochondria. Biochem Pharmacol 2007;74:992-1002.

39. Zakeri Z, Lockshin RA. Cell death: history and future. Adv Exp Med Biol 2008;615:1-11.

40. Riedl SJ, Salvesen GS. The apoptosome: signalling platform of cell death. Nat Rev Mol Cell Biol 2007;8:405-13.

41. Powis G, Montfort WR. Properties and biological activities of thioredoxins. Annu Rev Pharmacol Toxicol 2001;41:261-95.

42. Wang J, Kobayashi M, Sakurada K, Imamura M, Moriuchi T, Hosokawa M. Possible roles of an adult T-cell leukemia (ATL)-derived factor/thioredoxin in the drug resistance of ATL to Adriamycin. Blood 1997:89:2480-7. 
43. Yokomizo A, Ono M, Nanri H, Makino Y, Ohga T, Wada M et al. Cellular levels of thioredoxin associated with drug sensitivity to cisplatin, mitomycin $\mathrm{C}$, doxorubicin, and etoposide. Cancer Res $1995 ; 55: 4293-6$.

44. Nishinaka Y, Nakamura H, Masutani H, Yodoi J. Redox control of cellular function by thioredoxin: A new therapeutic direction in host defense. Arch Immunol Ther Exp 2001;49: 285-92.

45. Nordberg J, Arnér ESJ. Reactive oxygen species, antioxidants, and the mammalian thioredoxin system. Free Radic Biol Med 2001;31:1287-1312.

46. Sadler PJ, Guo Z. Metal complexes in medicine: design and mechanism of action. Pure Appl Chem 1998;7:863-71.

47. Christodoulou J, Sadler PJ, Tucker A. ${ }^{1} \mathrm{H}$ NMR of albumin in human blood plasma: drug binding and redox reaction at Cys34. FEBS Lett 1995;376:1-5.

48. Snyder RM, Mirabelli CK, Crooke ST. Cellular association, intracellular distribution, and efflux of auranofin via sequential ligand exchange reactions. Biochem Pharm 1986;35:923-32.

49. Chaudière J, Tappel AL. Interaction of gold(I) with the active site of selenium-glutathione peroxidase. J Inorg Biochem 1984;20:313-25.

50. Roberts JR, Shaw CF III. Inhibition of erythrocyte selenium-glutathione peroxidase by auranofin analogues and metabolites. Biochem Pharmacol 1998;55:1291-9.

51. Sadler PJ. The comparative evaluation of the physical and chemical properties of gold compounds. J Rheumatol Suppl 1982;8:71-8.

52. Pearson RG., Acids and Base. Science 1966;151:151-177.

53. Lee MT, Ahmed T, Haddad R, Friedman ME. Inhibition of several enzymes by gold compounds. II. beta-Glucuronidase, acid phosphatase and L-malate dehydrogenase by sodium thiomalatoraurate (I), sodium thiosulfatoaurate (I) and thioglucosoaurate (I). J Enzyme Inhib 1989;3:35-47.

54. Rigobello MP, Gandin V, Folda A, Rundlöf AK, Fernandes AP, Bindoli A, Marzano C, Björnstedt M. Treatment of human cancer cells with selenite or tellurite in combination with auranofin enhances 
cell death due to redox shift. Free Rad Biol Med 2009, Accepted manuscript, doi:10.1016/j.freeradbiomed.2009.05.027.

55. Friebolin W, Schillling G, Zöller M, Amtmann E. Antitumoral activity of non-platinum xanthate complexes. J Med Chem 2005;48:7925-31.

56. Meng A, Luberto C, Meier P, Bai A, Yang X, Hannun YA et al. Sphingomyelin synthase as a potential target for D609-induced apoptosis in U937 human monocytic leukemia cells. Exp Cell Res 2004;292:385-92.

57. Park SJ, Kim IS. The role of p38 MAPK activation in auranofin-induced apoptosis of human promyelocytic leukaemia HL-60 cells. Br J Pharmacol 2005;146:506-13.

58. Thomas, E. L. In: Pruitt KM, Tenovou JO editors. The Lactoperoxidase System, Chemistry and Biological Significance, Marcel Dekker, New York, 1985, p 31-53.

59. Arlandson M, Decker T, Roongta VA, Bonilla L, Mayo KH, MacPherson JC et al. Eosinophil peroxidase oxidation of thiocyanate. J Biol Chem 2001;276:215-24.

60. Berger RJF, Patzschke M, Schneider D, Schmidbaur H, Sundholm D. Isomeric mono- and bis[(phosphane)gold(I)] thiocyanate complexes. Chem Eur J 2005;11:3574-82.

61. Hickey JL, Ruhayel RA, Barnard PJ, Baker MV, Berners-Price SJ, Filipovska A. Mitochondriatargeted chemotherapeutics: the rational design of gold(I) N-heterocyclic carbene complexes that are selectively toxic to cancer cells and target protein selenols in preference to thiols. J Am Chem Soc 2008;130:12570-1.

62. Ott I, Qian X, Xu Y, Vlecken DHW, Marques IJ, Kubutat D et al. A gold(I) phosphine complex containing a naphthalimide ligand functions as a TrxR inhibiting antiproliferative agent and angiogenesis inhibitor. J Med Chem 2009;52:763-70.

63. Barnard PJ, Berners-Price SJ. Targeting the mitochondrial cell death pathway with gold compounds. Coord Chem Rev 2007;251:1889-1902. 
1

2

3

4

5

6

7

8

9

10

11

12

13

14

15

16

17

18

19

20

21

22

23

24

25

26

27

28

29

30

31

32

33

34

35

36

37

38

39

40

41

42

43

44

45

46

47

48

49

50

51

52

53

54

55

56

57

58

59

60

61

62

63

64

Page 34 of 50 
Table 1. Physico-chemical data of phosphine gold(I) complexes utilised in this study.

\begin{tabular}{|c|c|c|c|c|}
\hline Gold(I) complex & ${ }^{31} \mathrm{P}^{a}$ & $\mathrm{Et}_{3} \mathrm{P}-\cdots$ & $---(\mathrm{X})^{b}$ & $\mathrm{P}-\mathrm{Au}-\mathrm{-} \mathrm{X}^{c}$ \\
\hline $\mathrm{PEt}_{3}$ & -17.80 & & & \\
\hline$\left[\mathrm{AuCl}\left(\mathrm{PEt}_{3}\right)\right]$ & 32.32 & $\ldots$ & $2.306(\mathrm{Cl})$ & 178.7 \\
\hline$\left[\mathrm{AuBr}\left(\mathrm{PEt}_{3}\right)\right]$ & 35.18 & & & \\
\hline$\left[\mathrm{Au}(\mathrm{CN})\left(\mathrm{PEt}_{3}\right)\right]$ & 36.81 & 2.288 & $1.971(\mathrm{C})$ & 176.6 \\
\hline$\left[\mathrm{Au}(\mathrm{SCN})\left(\mathrm{PEt}_{3}\right)\right]$ & 37.23 & & & \\
\hline$\left[\mathrm{Au}(\mathrm{dedc})\left(\mathrm{PEt}_{3}\right)\right]$ & 34.76 & 2.245 & $2.337(\mathrm{~S})$ & 173.8 \\
\hline$\left[\mathrm{Au}(\mathrm{xant})\left(\mathrm{PEt}_{3}\right)\right]$ & 36.65 & 2.265 & $2.328(\mathrm{~S})$ & 177.7 \\
\hline$\left[\mathrm{Au}(\mathrm{tu})\left(\mathrm{PEt}_{3}\right)\right][\mathrm{Cl}]^{c}$ & 36.31 & & & \\
\hline $\begin{array}{l}{\left[\mathrm{Au}(\mathrm{S}-\text { thiog })\left(\mathrm{PEt}_{3}\right)\right](\mathbf{8})} \\
\text { 'auranofin' }\end{array}$ & 38.06 & 2.259 & $2.293(\mathrm{~S})$ & 173.6 \\
\hline
\end{tabular}

${ }^{a}$ Unless otherwise specified, NMR spectra are recorded in chloroform- $d$,

${ }^{b} \mathrm{Au}-\mathrm{P}$ and $\mathrm{Au}-\mathrm{X}$ distances in $\AA$.

${ }^{c} \mathrm{P}-\mathrm{Au}-\mathrm{X}$ angle in degree $\left({ }^{\circ}\right)$.

${ }^{d}$ NMR spectra recorded in dimethylsulfoxide- $d_{6}$. 
Table 2. Cytotoxicity of gold(I) complexes

\begin{tabular}{|c|c|c|c|c|c|c|c|}
\hline \multirow{2}{*}{ Compound } & & \multicolumn{6}{|c|}{$\mathrm{IC}_{50}(\mu \mathrm{M}) \pm$ S.D. } \\
\hline & & HL60 & A549 & MCF-7 & A375 & НCТ-15 & HeLa \\
\hline$\left[\mathrm{AuCl}\left(\mathrm{PEt}_{3}\right)\right]$ & (1) & $0.52 \pm 0.13$ & $0.85 \pm 0.01$ & $0.84 \pm 0.01$ & $0.78 \pm 0.31$ & $0.97 \pm 0.17$ & $0.90 \pm 0.21$ \\
\hline$\left[\mathrm{AuBr}\left(\mathrm{PEt}_{3}\right)\right]$ & (2) & $0.62 \pm 0.06$ & $1.21 \pm 0.54$ & $1.44 \pm 0.41$ & $1.02 \pm 1.00$ & $1.08 \pm 0.82$ & $0.63 \pm 0.32$ \\
\hline$\left[\mathrm{Au}(\mathrm{CN})\left(\mathrm{PEt}_{3}\right)\right]$ & (3) & $0.19 \pm 0.07$ & $0.41 \pm 0.06$ & $0.45 \pm 0.12$ & $0.21 \pm 0.23$ & $0.08 \pm 0.01$ & $0.09 \pm 0.02$ \\
\hline$\left[\mathrm{Au}(\mathrm{SCN})\left(\mathrm{PEt}_{3}\right)\right]$ & (4) & $0.21 \pm 0.12$ & $0.71 \pm 0.02$ & $0.65 \pm 0.11$ & $0.37 \pm 0.29$ & $0.32 \pm 0.02$ & $0.18 \pm 0.01$ \\
\hline$\left[\mathrm{Au}(\mathrm{dedc})\left(\mathrm{Pet}_{3}\right)\right]$ & (5) & $0.96 \pm 1.21$ & $1.22 \pm 0.96$ & $1.63 \pm 0.58$ & $1.47 \pm 0.77$ & $0.92 \pm 0.01$ & $0.54 \pm 0.07$ \\
\hline$\left[\mathrm{Au}(\mathrm{xant})\left(\mathrm{PEt}_{3}\right)\right]$ & (6) & $0.19 \pm 0.06$ & $0.33 \pm 0.47$ & $0.41 \pm 0.21$ & $0.13 \pm 0.27$ & $0.61 \pm 0.13$ & $0.13 \pm 0.61$ \\
\hline$\left[\mathrm{Au}(\mathrm{tu})\left(\mathrm{PEt}_{3}\right)\right][\mathrm{Cl}]$ & (7) & $2.84 \pm 1.29$ & $3.01 \pm 1.01$ & $3.28 \pm 1.12$ & $2.23 \pm 1.03$ & $2.75 \pm 1.43$ & $1.84 \pm 0.25$ \\
\hline Auranofin & $(8)$ & $0.23 \pm 0.11$ & $0.75 \pm 0.05$ & $0.98 \pm 0.32$ & $0.34 \pm 0.21$ & $0.11 \pm 0.02$ & $0.15 \pm 0.03$ \\
\hline Cisplatin & & $4.56 \pm 1.13$ & $29.21 \pm 1.92$ & $19.04 \pm 1.51$ & $2.37 \pm 1.23$ & $20.34 \pm 1.31$ & $8.50 \pm 1.51$ \\
\hline
\end{tabular}

S.D. $=$ standard deviation

$\mathrm{IC}_{50}$ values were calculated by probit analysis $\left(P<0.05, \chi^{2}\right.$ test $)$. Cells $\left(5-8 \cdot 10^{4} \cdot \mathrm{mL}^{-1}\right)$ were treated for $72 \mathrm{~h}$ with increasing concentrations of tested compounds. Cytotoxicity was assessed by MTT test. 
Table 3. Cisplatin cross-resistance profiles

\begin{tabular}{|c|c|c|c|c|}
\hline \multirow{3}{*}{ Compound } & \multicolumn{4}{|c|}{ Human ovarian adenocarcinoma cells } \\
\hline & \multirow{2}{*}{$\begin{array}{c}2008 \\
\mathrm{IC}_{50}(\mu \mathrm{M}) \pm \text { S.D. }\end{array}$} & \multirow{2}{*}{$\begin{array}{c}\mathrm{C} 13 \\
\mathrm{IC}_{50}(\mu \mathrm{M}) \pm \mathrm{S} . \mathrm{D} .\end{array}$} & \multirow[t]{2}{*}{ R.F. } & \multirow{2}{*}{$\begin{array}{c}\text { RH4 } \\
\mathrm{IC}_{50}(\mu \mathrm{M}) \pm \text { S.D. }\end{array}$} \\
\hline & & & & \\
\hline$\left[\mathrm{AuCl}\left(\mathrm{PEt}_{3}\right)\right]$ & $1.12 \pm 0.29$ & $1.05 \pm 0.43$ & 0.93 & $0.91 \pm 0.53$ \\
\hline$\left[\mathrm{AuBr}\left(\mathrm{PEt}_{3}\right)\right]$ & $1.61 \pm 0.71$ & $1.06 \pm 0.68$ & 0.66 & $0.93 \pm 0.47$ \\
\hline$\left[\mathrm{Au}(\mathrm{CN})\left(\mathrm{PEt}_{3}\right)\right]$ & $0.99 \pm 0.01$ & $0.96 \pm 0.25$ & 0.96 & $0.98 \pm 0.12$ \\
\hline$\left[\mathrm{Au}(\mathrm{SCN})\left(\mathrm{PEt}_{3}\right)\right]$ & $0.95 \pm 0.02$ & $0.94 \pm 0.04$ & 0.93 & $0.12 \pm 0.59$ \\
\hline$\left[\mathrm{Au}(\mathrm{dedc})\left(\mathrm{PEt}_{3}\right)\right]$ & $0.86 \pm 1.38$ & $0.87 \pm 0.98$ & 1.00 & $0.81 \pm 0.45$ \\
\hline$\left[\mathrm{Au}(\mathrm{xant})\left(\mathrm{PEt}_{3}\right)\right] \quad(\mathbf{6})$ & $0.67 \pm 0.65$ & $0.66 \pm 0.02$ & 0.98 & $0.68 \pm 0.58$ \\
\hline$\left[\mathrm{Au}(\mathrm{tu})\left(\mathrm{PEt}_{3}\right)\right][\mathrm{Cl}] \quad(7)$ & $4.21 \pm 2.30$ & $4.13 \pm 0.74$ & 1.08 & $4.09 \pm 2.11$ \\
\hline Auranofin & $1.01 \pm 0.97$ & $0.43 \pm 0.09$ & 0.43 & $0.89 \pm 0.72$ \\
\hline Cisplatin & $10.14 \pm 1.43$ & $89.18 \pm 2.08$ & 8.79 & $26.61 \pm 1.53$ \\
\hline \multirow{3}{*}{ Compound } & \multicolumn{4}{|c|}{ Human cervix carcinoma cells } \\
\hline & A431 & $\mathrm{A} 431 / \mathrm{Pt}$ & & R.F. \\
\hline & $\mathrm{IC}_{50}(\mu \mathrm{M}) \pm \mathrm{S} . \mathrm{D}$ & $\mathrm{IC}_{50}(\mu \mathrm{M}) \pm \mathrm{S} . \mathrm{I}$ & & \\
\hline$\left[\mathrm{AuCl}\left(\mathrm{PEt}_{3}\right)\right]$ & $0.95 \pm 0.11$ & $1.08 \pm 0.91$ & & 1.14 \\
\hline$\left[\mathrm{AuBr}\left(\mathrm{PEt}_{3}\right)\right]$ & $1.75 \pm 0.002$ & $1.77 \pm 0.61$ & & 1.10 \\
\hline$\left[\mathrm{Au}(\mathrm{CN})\left(\mathrm{PEt}_{3}\right)\right]$ & $0.97 \pm 0.17$ & $0.98 \pm 0.13$ & & 1.01 \\
\hline$\left[\mathrm{Au}(\mathrm{SCN})\left(\mathrm{PEt}_{3}\right)\right]$ & $0.95 \pm 0.52$ & $0.97 \pm 0.16$ & & 1.02 \\
\hline$\left[\mathrm{Au}(\mathrm{dedc})\left(\mathrm{PEt}_{3}\right)\right]$ & $2.02 \pm 0.75$ & $2.06 \pm 0.72$ & & 1.02 \\
\hline$\left[\mathrm{Au}(\mathrm{xant})\left(\mathrm{PEt}_{3}\right)\right]$ & $0.53 \pm 0.76$ & $0.27 \pm 1.44$ & & 0.94 \\
\hline$\left[\mathrm{Au}(\mathrm{tu})\left(\mathrm{PEt}_{3}\right)\right][\mathrm{Cl}]$ & $2.01 \pm 0.42$ & $1.87 \pm 0.12$ & & 0.98 \\
\hline Auranofin & $2.01 \pm 1.54$ & $1.87 \pm 0.50$ & & 0.93 \\
\hline Cisplatin & $22.06 \pm 2.21$ & $57.76 \pm 3.94$ & & 2.61 \\
\hline
\end{tabular}

S.D. $=$ standard deviation 
$\mathrm{IC}_{50}$ values were calculated by probit analysis $\left(P<0.05, X^{2}\right.$ test $)$. Cells $\left(3-8 \cdot 10^{4} \cdot \mathrm{ml}^{-1}\right)$ were treated for 48 hrs with increasing concentrations of tested compounds dissolved in DMSO. Cytotoxicity was assessed by MTT test. 
Table 4. MDR cross-resistance profiles

\begin{tabular}{|c|c|c|c|c|}
\hline \multirow{3}{*}{ Compound } & & \multicolumn{3}{|c|}{ Human small cell lung carcinoma cells } \\
\hline & & \multirow{2}{*}{$\begin{array}{c}\mathrm{U} 1285 \\
\mathrm{IC}_{50}(\mu \mathrm{M}) \pm \text { S.D. }\end{array}$} & \multirow{2}{*}{$\begin{array}{c}\text { U1285dox } \\
\mathrm{IC}_{50}(\mu \mathrm{M}) \pm \text { S.D. }\end{array}$} & \multirow[t]{2}{*}{ R.F. } \\
\hline & & & & \\
\hline$\left[\mathrm{AuCl}\left(\mathrm{PEt}_{3}\right)\right]$ & (1) & $1.29 \pm 0.31$ & $1.18 \pm 0.11$ & 0.92 \\
\hline$\left[\mathrm{AuBr}\left(\mathrm{PEt}_{3}\right)\right]$ & (2) & $1.43 \pm 0.17$ & $1.41 \pm 0.36$ & 0.99 \\
\hline$\left[\mathrm{Au}(\mathrm{CN})\left(\mathrm{PEt}_{3}\right)\right]$ & (3) & $0.73 \pm 0.29$ & $0.72 \pm 0.51$ & 0.98 \\
\hline$\left[\mathrm{Au}(\mathrm{SCN})\left(\mathrm{PEt}_{3}\right)\right]$ & $(4)$ & $0.62 \pm 0.23$ & $0.61 \pm 0.36$ & 0.98 \\
\hline$\left[\mathrm{Au}(\mathrm{dedc})\left(\mathrm{Pet}_{3}\right)\right]$ & (5) & $2.33 \pm 1.04$ & $2.46 \pm 0.93$ & 1.06 \\
\hline$\left[\mathrm{Au}(\mathrm{xant})\left(\mathrm{Pet}_{3}\right)\right]$ & (6) & $0.79 \pm 1.56$ & $0.43 \pm 1.43$ & 0.54 \\
\hline$\left[\mathrm{Au}(\mathrm{tu})\left(\mathrm{PEt}_{3}\right)\right][\mathrm{Cl}]$ & (7) & $6.62 \pm 1.98$ & $6.69 \pm 1.39$ & 1.01 \\
\hline Auranofin & $(8)$ & $0.92 \pm 1.43$ & $0.67 \pm 0.45$ & 0.73 \\
\hline Doxorubicin & & $1.01 \pm 0.34$ & $87.07 \pm 2.97$ & 86.21 \\
\hline
\end{tabular}

Human colon adenocarcinoma cells

$\begin{array}{llll} & \text { Lompound } & \text { LoVo MDR }\end{array}$

$$
\mathrm{IC}_{50}(\mu \mathrm{M}) \pm \text { S.D. } \quad \mathrm{IC}_{50}(\mu \mathrm{M}) \pm \text { S.D. }
$$

\begin{tabular}{lcccc}
\hline$\left[\mathrm{AuCl}\left(\mathrm{PEt}_{3}\right)\right]$ & $\mathbf{( 1 )}$ & $1.79 \pm 0.56$ & $1.47 \pm 0.59$ & 0.82 \\
\hline$\left[\mathrm{AuBr}\left(\mathrm{PEt}_{3}\right)\right]$ & $\mathbf{( 2 )}$ & $1.85 \pm 0.77$ & $1.21 \pm 0.86$ & 0.65 \\
\hline$\left[\mathrm{Au}(\mathrm{CN})\left(\mathrm{PEt}_{3}\right)\right]$ & $\mathbf{( 3 )}$ & $0.67 \pm 0.08$ & $0.65 \pm 0.07$ & 0.97 \\
\hline$\left[\mathrm{Au}(\mathrm{SCN})\left(\mathrm{PEt}_{3}\right)\right]$ & $\mathbf{( 4 )}$ & $0.69 \pm 0.33$ & $0.61 \pm 0.65$ & 0.88 \\
\hline$\left[\mathrm{Au}\left(\mathrm{dedc}^{\prime}\right)\left(\mathrm{Pet}_{3}\right)\right]$ & $\mathbf{( 5 )}$ & $1.33 \pm 1.54$ & $1.04 \pm 1.50$ & 0.78 \\
\hline$\left[\mathrm{Au}\left(\mathrm{xant}^{\prime}\left(\mathrm{Pet}_{3}\right)\right]\right.$ & $\mathbf{( 6 )}$ & $0.69 \pm 1.56$ & $0.57 \pm 1.59$ & 0.82 \\
\hline$\left[\mathrm{Au}(\right.$ tu $\left.)\left(\mathrm{PEt}_{3}\right)\right][\mathrm{Cl}]$ & $\mathbf{( 7 )}$ & $6.06 \pm 1.98$ & $6.28 \pm 1.67$ & 1.04 \\
\hline Auranofin & $\mathbf{( 8 )}$ & $1.12 \pm 0.74$ & $1.11 \pm 0.45$ & 1.01 \\
\hline Doxorubicin & & $1.46 \pm 2.30$ & $44.89 \pm 0.90$ & 30.75 \\
\hline
\end{tabular}

S.D. $=$ standard deviation 
$\mathrm{IC}_{50}$ values were calculated by probit analysis $\left(P<0.05, X^{2}\right.$ test $)$. Cells $\left(3-8 \cdot 10^{4} \cdot \mathrm{ml}^{-1}\right)$ were treated for $48 \mathrm{hrs}$ with increasing concentrations of tested compounds. Cytotoxicity was assessed by MTT test. 
Table 5 Inhibitory effect of gold(I) compounds on rat cytosolic (TrxR1) and mitochondrial (TrxR2) thioredoxin reductases, on glutathione reductase (GR) and glutathione peroxidase (GPx).

\begin{tabular}{lccccc}
\multicolumn{1}{c}{ Compound } & \multicolumn{2}{c}{ TrxR1 } & TrxR2 & GR & GPx \\
\hline$\left[\mathrm{AuCl}\left(\mathrm{PEt}_{3}\right)\right]$ & $\mathbf{( 1 )}$ & $1.80 \pm 0.60$ & $9.00 \pm 0.34$ & $19.00 \pm 0.79$ & $79.00 \pm 3.00$ \\
{$\left[\mathrm{AuBr}\left(\mathrm{PEt}_{3}\right)\right]$} & $\mathbf{( 2 )}$ & $1.50 \pm 0.20$ & $7.00 \pm 0.30$ & $17.29 \pm 0.67$ & $89.00 \pm 4.00$ \\
{$\left[\mathrm{Au}(\mathrm{CN})\left(\mathrm{PEt}_{3}\right)\right]$} & $\mathbf{( 3 )}$ & $1.10 \pm 0.20$ & $5.00 \pm 0.23$ & $77.88 \pm 1.40$ & $80.00 \pm 3.00$ \\
{$\left[\mathrm{Au}(\mathrm{SCN})\left(\mathrm{PEt}_{3}\right)\right]$} & $\mathbf{( 4 )}$ & $1.80 \pm 0.23$ & $7.80 \pm 0.29$ & $7.86 \pm 0.34$ & $72.00 \pm 2.60$ \\
{$\left[\mathrm{Au}\left(\mathrm{dedc}_{50}\right)\left(\mathrm{Pet}_{3}\right)\right]$} & $\mathbf{( 5 )}$ & $0.31 \pm 0.45$ & $0.70 \pm 0.32$ & $28.01 \pm 0.45$ & $68.00 \pm 2.45$ \\
{$\left[\mathrm{Au}(\mathrm{xant})\left(\mathrm{Pet}_{3}\right)\right]$} & $\mathbf{( 6 )}$ & $0.72 \pm 0.50$ & $3.60 \pm 1.20$ & $18.10 \pm 1.00$ & $40.27 \pm 2.00$ \\
{$\left[\mathrm{Au}(\mathrm{tu})\left(\mathrm{PEt}_{3}\right)\right][\mathrm{Cl}] \mathbf{( 7 )}$} & $1.00 \pm 0.30$ & $10.00 \pm 0.42$ & $50.37 \pm 0.98$ & $17.53 \pm 1.34$ \\
$\mathrm{Auranofin}$ & $\mathbf{( 8 )}$ & $0.80 \pm 0.24$ & $3.70 \pm 0.24$ & $30.00 \pm 1.00$ & $63.00 \pm 2.00$ \\
\hline
\end{tabular}

S.D. = standard deviation

Thioredoxin reductase activity was assayed by measuring NADPH- dependent reduction of DTNB at $412 \mathrm{~nm}$; glutathione reductase activity and glutathione peroxidase activities were followed at 340 $\mathrm{nm}$. $\mathrm{IC}_{50}$ values were calculated by probit analysis $\left(P<0.05, X^{2}\right.$ test $)$. 
Figure 1

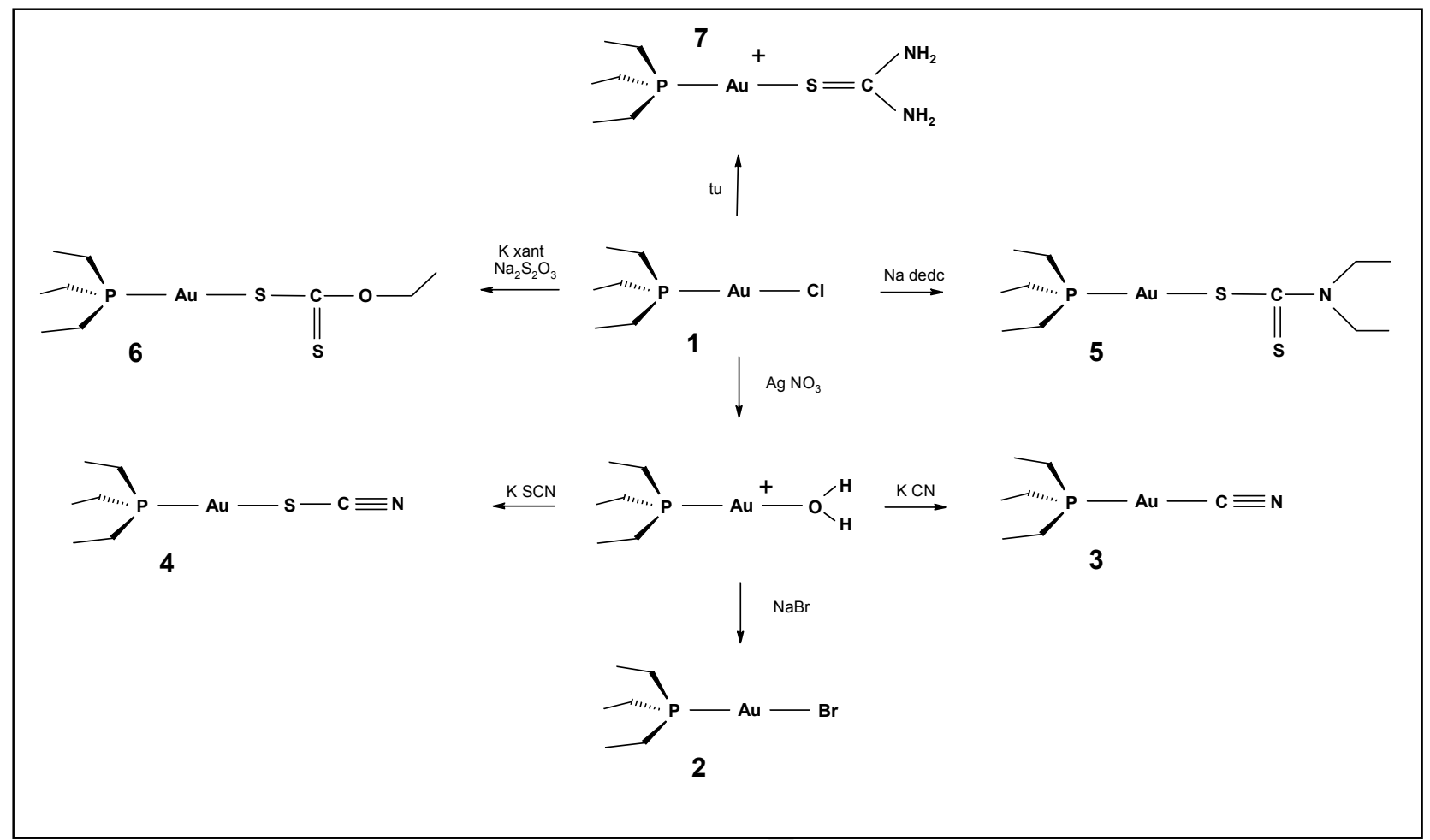


Figure 2.
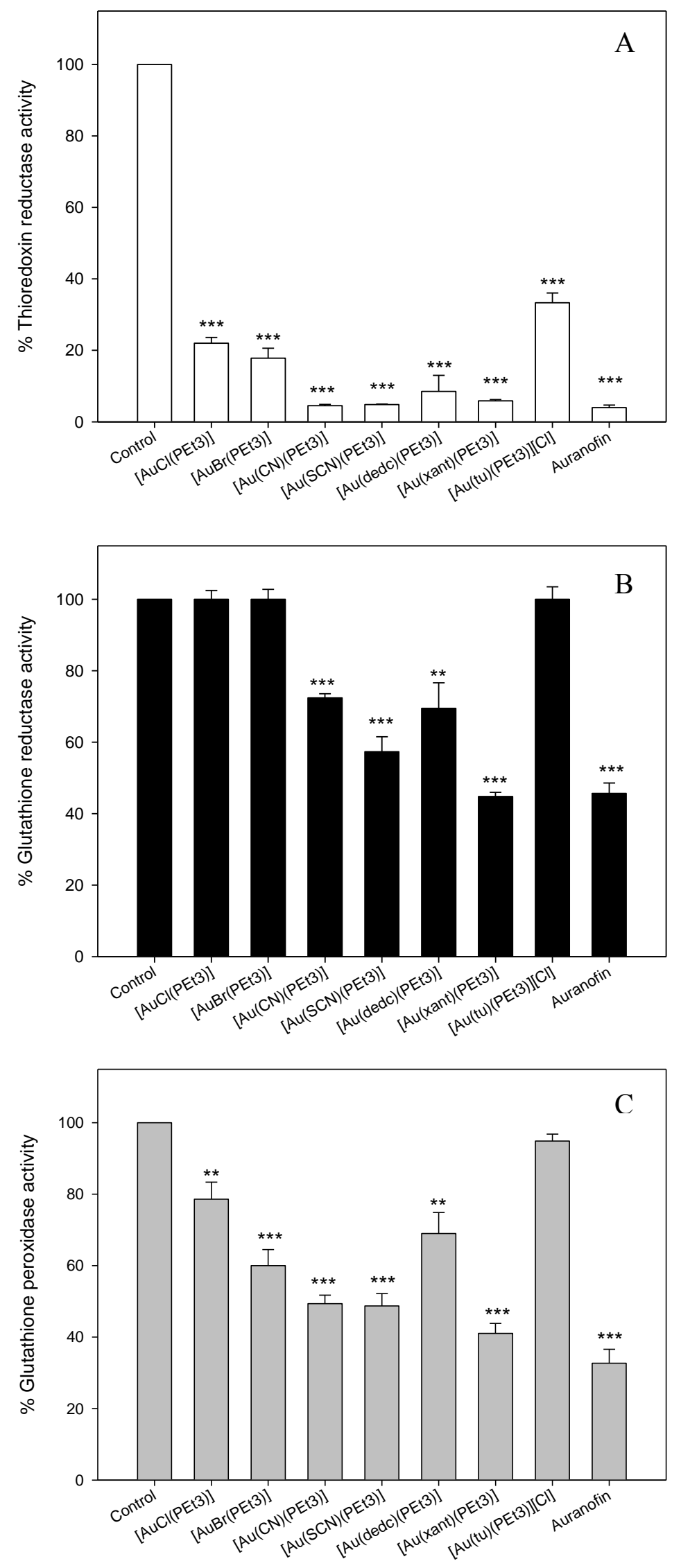
Figure 3.

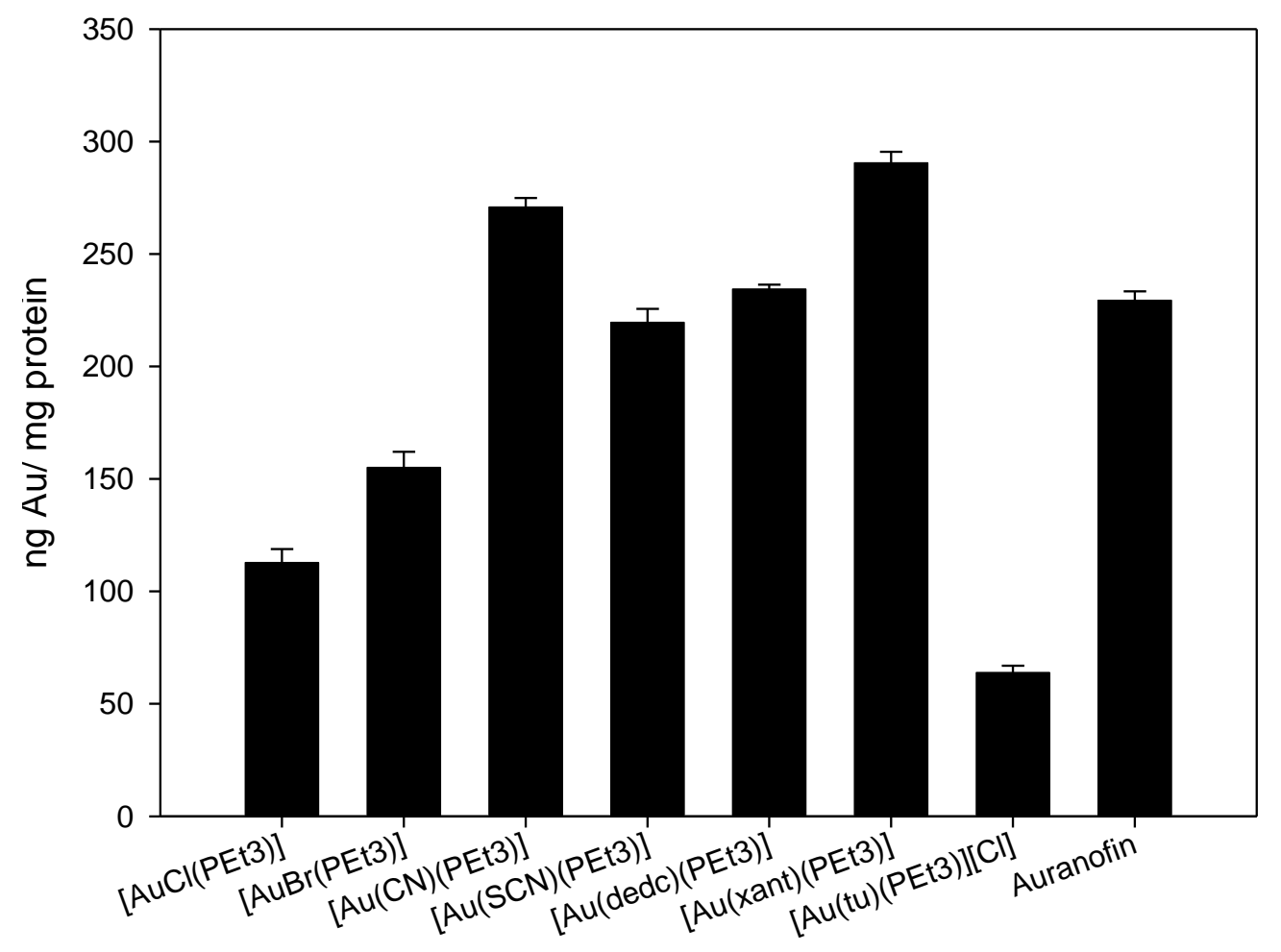


Figure 4.
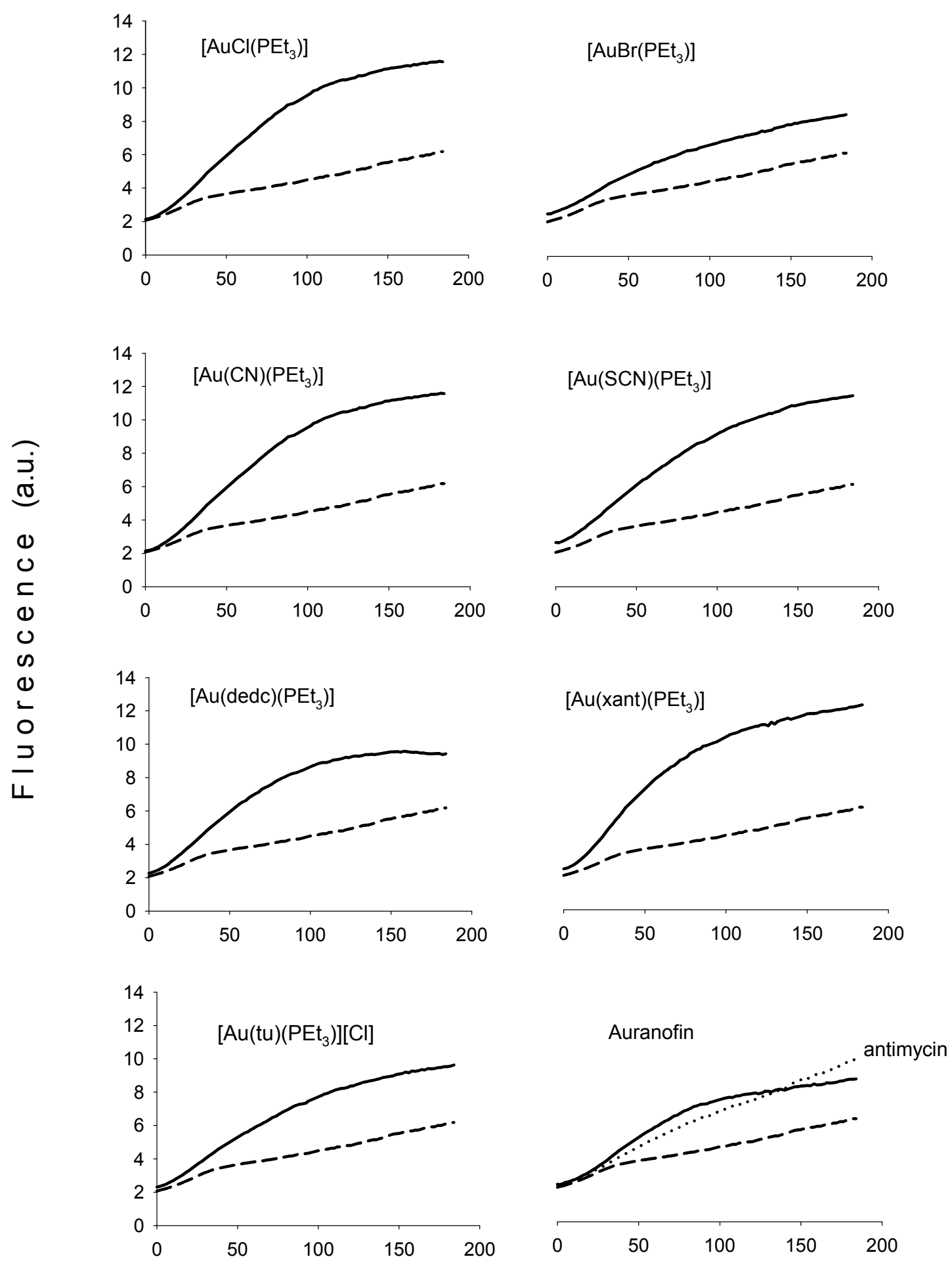

Time (min) 
Figure 5.
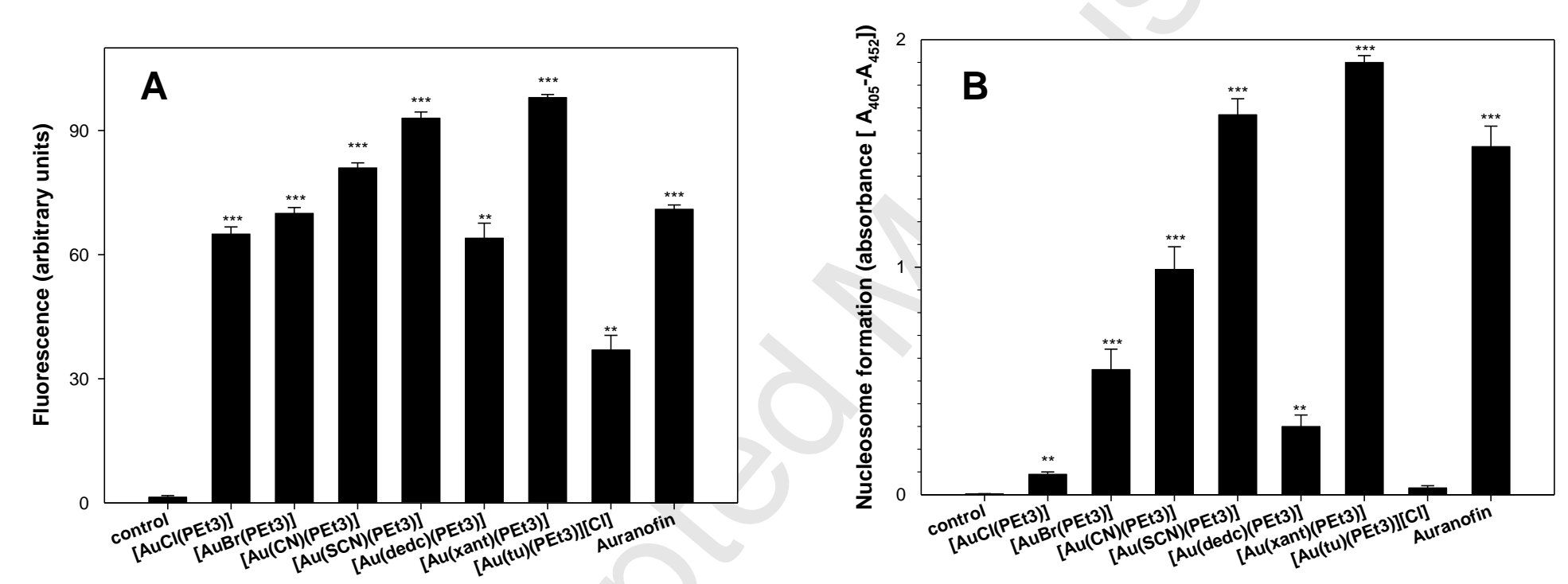
Figure 5

C

Control

[Au(xant) $\left.\left(\mathrm{PEt}_{3}\right)\right]$

DAPI

Hoechst 33342

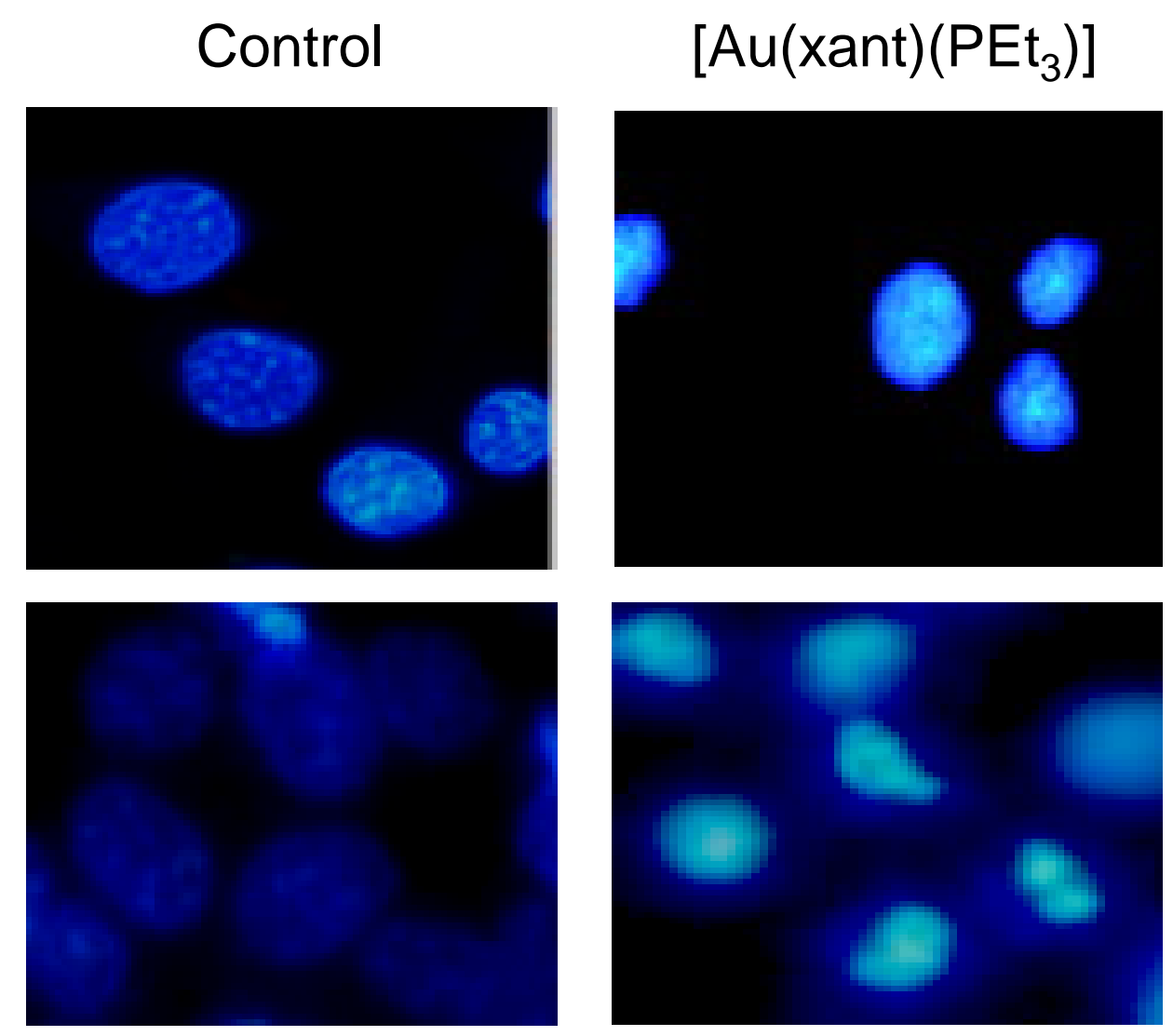


Figure 6.
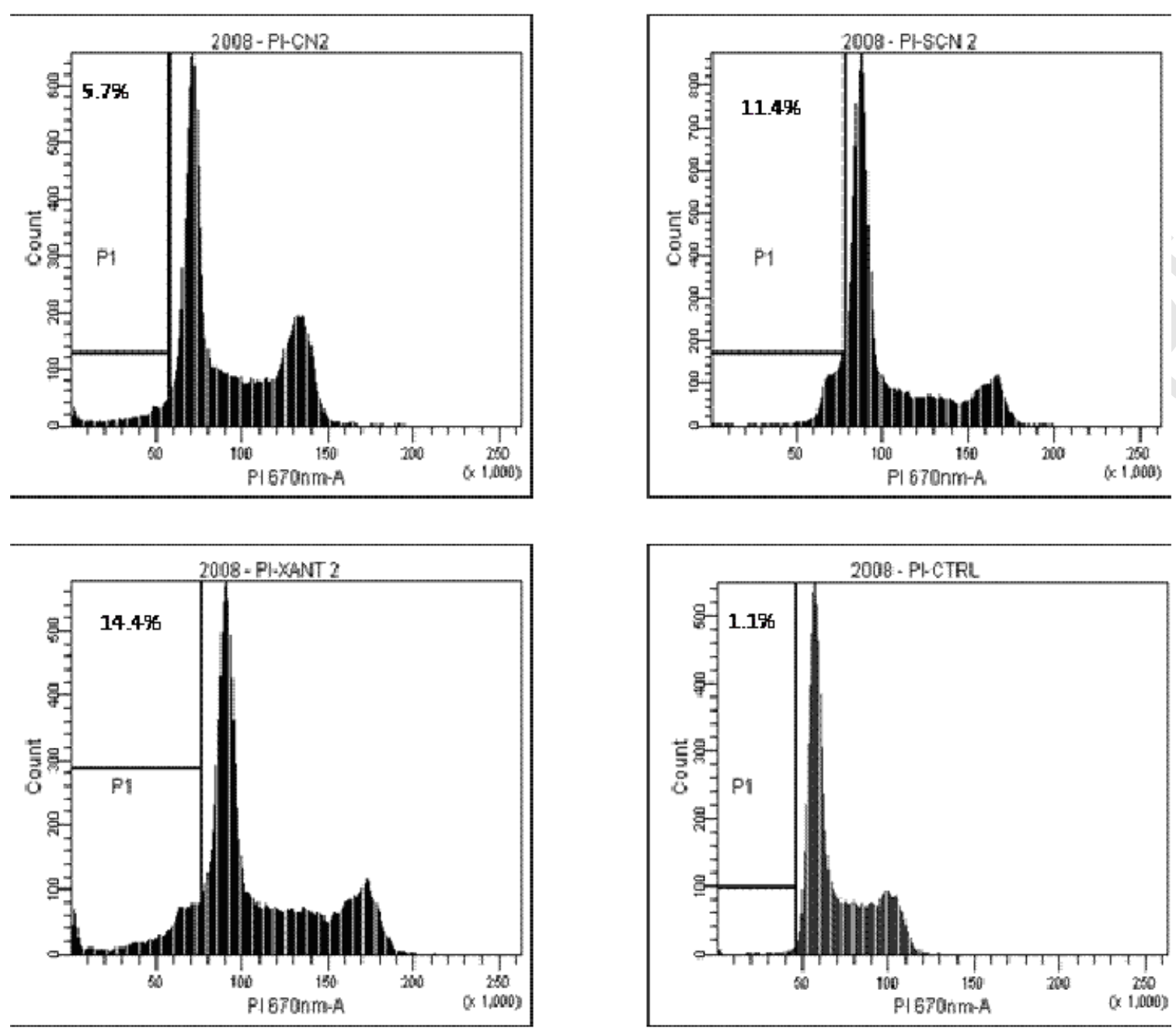
Graphical abstract
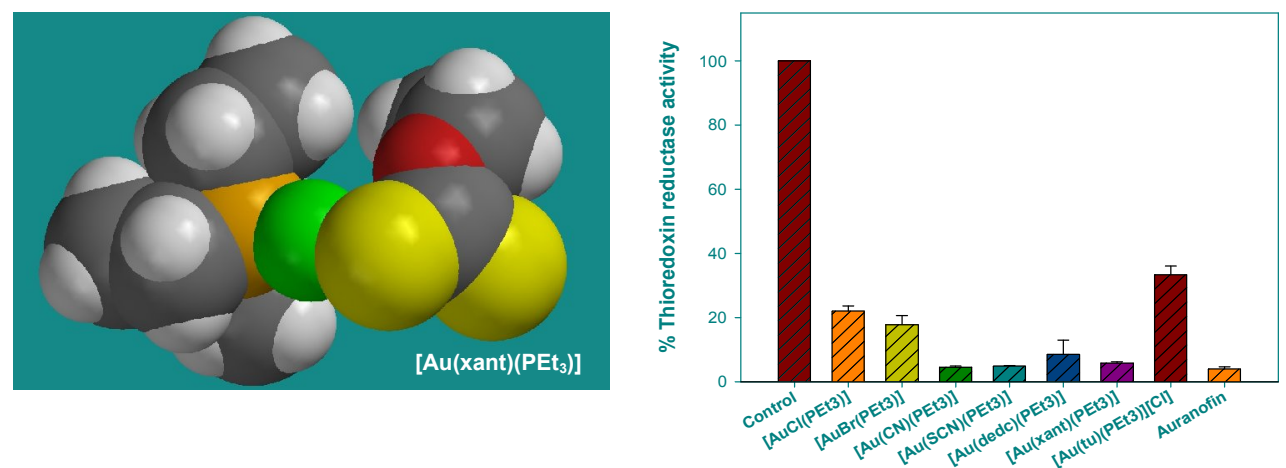

Page 50 of 50 